Journal of Social Sciences (COES\&RJ-JSS)

ISSN (E): 2305-9249 ISSN (P): 2305-9494

Publisher: Centre of Excellence for Scientific \& Research Journalism, COES\&RJ LLC Online Publication Date: $1^{\text {st }}$ October 2018

Online Issue: Volume 7, Number 4, October 2018

https://doi.org/10.25255/jss.2018.7.4.277.302

\title{
The Practicing Degree of Organizational Justice by the Administrative Leaders at the Jordanian Ministry of Education and its Relationship with the Subordinates' Performance and Trust in their Leaders
}

Dr. Faleh Salamah Al-Louzi*, Dr. Ala'aldin Alrowwad**, Dr. Ra'ed Masa'deh***

\begin{abstract}
:
This study aimed at identifying the practicing degree of organizational justice by the administrative leaders at the Jordanian Ministry of Education and its relationship with the subordinates' performance and trust in their leaders. In order to accomplish this aim, the study aimed at answering the following five questions:

What is the practicing degree of organizational justice by the administrative leaders at the Jordanian Ministry of Education from the viewpoint of the subordinates?

What is the performance level of the subordinates from the viewpoint of their leaders?

What is the trust degree between the administrative leaders in the Jordanian Ministry of Education and their subordinates from the viewpoint of the subordinates?

Is there a statistically significant relationship at $(\alpha \leq 0.05)$ between the practicing degree of organizational justice by the administrative leaders at the Jordanian Ministry of Education and the performance level of their subordinates?

Is there a statistically significant relationship at $(\alpha \leq 0.05)$ between the practicing degree of organizational justice by the administrative leaders at the Jordanian Ministry of Education and the subordinates' trust in them?

The study population consisted of all the Administrative Leaders, Division Heads, and the Subordinates in the Directorates of the Jordanian Ministry of Education \{(1548) subordinates, (18) of them are managing directors, (52) are specialized directors, (196) section heads, and (1282) subordinates.\} The study sample consisted of (486) individuals and included (18) General Directors, (52) Specialized Directors, (104) Division Heads and (312) subordinates. The researchers used a questionnaire with this instrument to collect data about the organizational justice of the administrative leaders, subordinats' performance, and trust between leaders and subordinates. The researchers employed content validity to insure validity of the three instruments and used test-retest for reliability. In order to answer the study questions, the means, standard deviations, and Person Correlation Coefficient have been used.

The study results have shown the following:

The practicing degree of organizational justice by the administrative leaders at the (MOE) was generally high in all its dimensions.

The performance level of the subordinates at the Ministry of Education (MOE) was high. The organizational trust between the administrative leaders in the Ministry of Education and their subordinates was high.

There was a statistically significant relationship at $(\alpha \leq 0.05)$ between the practicing degree of organizational justice and the performance level of subordinates.

There was a statistically significant relationship at $(\alpha \leq 0.05)$ between the practicing degree of organizational justice and the subordinates' trust in their leaders.
\end{abstract}

This work is licensed under a Creative Commons Attribution 4.0 International License. 
In light of these results, the researchers proposed a number of recommendations, some of which are:

Leaders should continue promoting organizational justice at the Ministry of Education as a substantial value in its culture.

Explanation of the positive relationship and its importance between organizational justice and subordinates' performance and their trust in their leaders to the middle management at the (MOE).

Conduct more studies about the relationship between the organizational justice and other variables such as work satisfaction and motivation.

\section{Keywords:}

Organizational Justice, Subordinates' Performance, Trust in Leaders, Jordan.

\section{Citation:}

Al-Louzi, Faleh Salamah; Alrowwad, Ala'aldin; Masa'deh, Ra'ed (2018); The Practicing Degree of Organizational Justice by the Administrative Leaders at the Jordanian Ministry of Education and its Relationship with the Subordinates' Performance and Trust in their Leaders; Journal of Social Sciences (COES\&RJ-JSS), Vol.7, No.4, pp:277-302;

https://doi.org/10.25255/jss.2018.7.4.277.302.

*Part-time Leacturer, Specialist in Educational Sciences, Amman, Jordan

**Department of Business Management, School of Business, The University of Jordan, Aqaba Branch, Jordan, a.alrowwad@ju.edu.jo

$* * *$ Department of Management Information Systems, School of Business, The University of Jordan, Amman, Jordan \& Dean of the Faculty of Management and Finance, The University of Jordan, Aqaba Branch, Jordan, r.masadeh@ju.edu.jo

\section{درجة ممارسة القادة الإداريين في وزارة التربية والتعليم الأردنية للعدالة التنظيمية وعلاقتها بالأداء الوظيفي للعاملين وثثتهم بقادتهم}




$$
\text { د. فالح سلامة اللوزي } 1 \text { ، د. علاءالدين الرواد² ، د.ر ائد مساعده3 }
$$

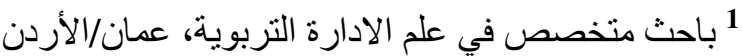

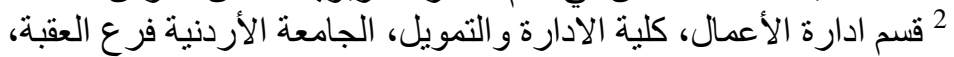

a.alrowwad@ju.edu.jo

3 قسم نظم المعلومات الإدارية، كلية الأعمال، الجامعة الأردنية، عمان/الأردن، عميد كلية الادارة

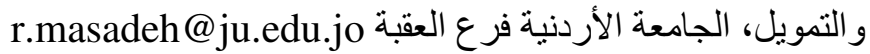

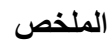

هدفت الدر اسة إلى تعرف درجة ممارسة القادة الاداريين في وزارة التربية و التعليم الأردنية للعدالة التنظيميـة و علاقتها

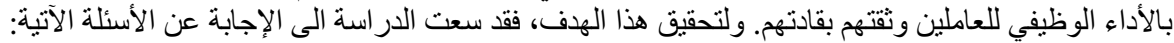

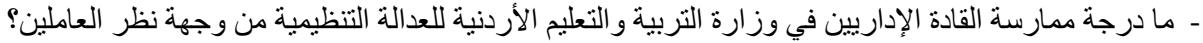

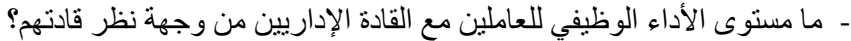

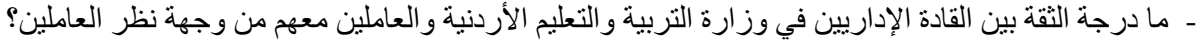

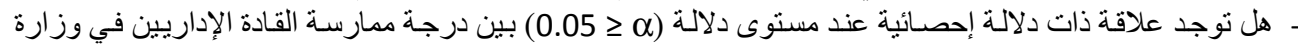

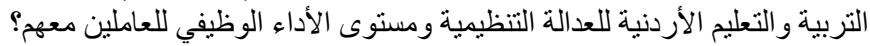

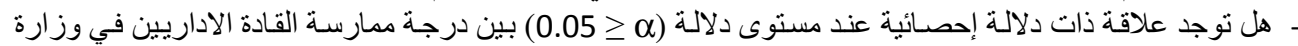

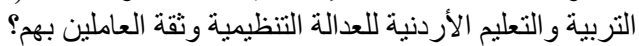

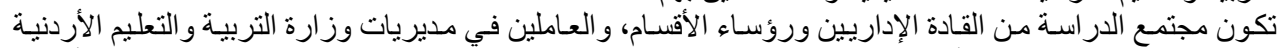

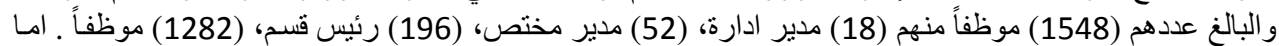

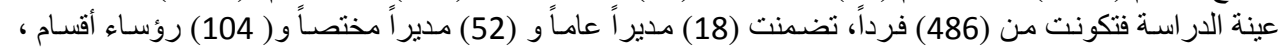

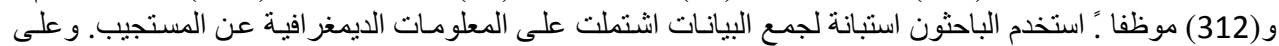

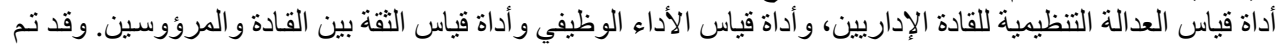

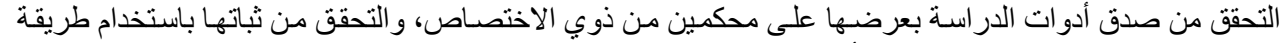
الاختبار و إعادة الاختبار . وللإجابة عن أسئلة الدر اسة تم استخدام المتوسطات الحسابية و الانحر افات المعياريـة ومعامل

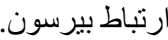
أظهرت نتائج الدر اسة مايلي:

كانت درجة ممارسة القادة الإداريين للعدالة الإنة التنظيمية مرتفعة بشكل عام وفي جميع أبعادها.

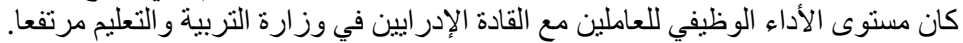

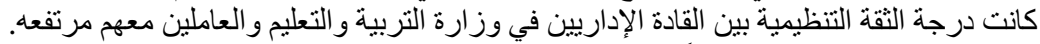

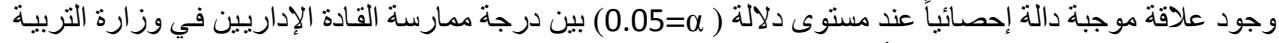

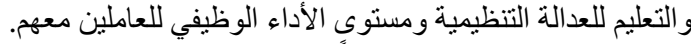

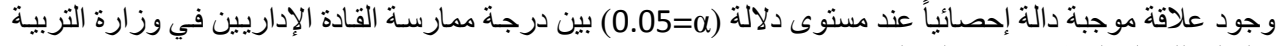

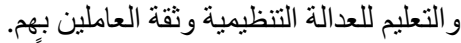

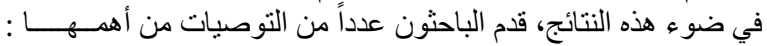

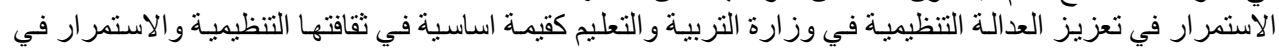
تقييمها.

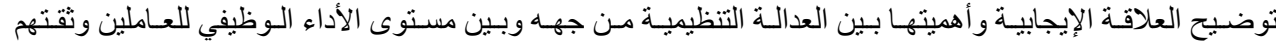

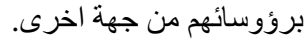

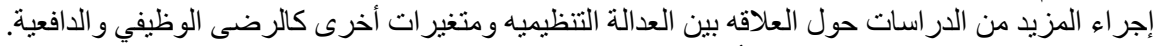
الكلمات المفتاحية: العدالة التنظيمية، الأداء الوظيفي، التئه التهاء بالقادة، الاردن. 


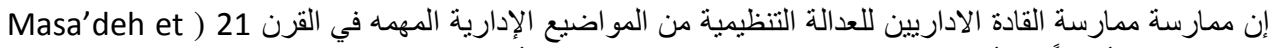

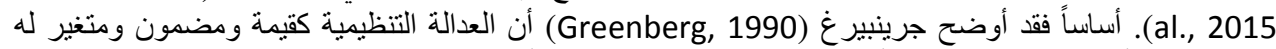
دلالاته في التأثير التظظيمي. ويمكن أن يفسر العديد من المتغيرات الأخرى المؤثرة في السلوك النّاء التنظيمي للعاملين في

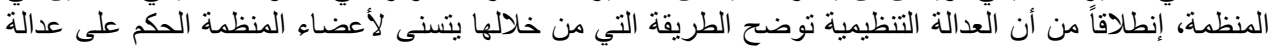

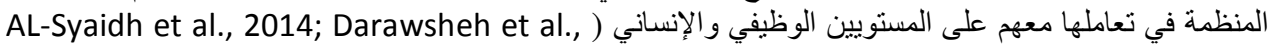
2016). وأكد بول وتريفنو وسيمس (Ball, Trevino, \& Sims, 1994) أن العاملين الذين يحسون بالعدالة من

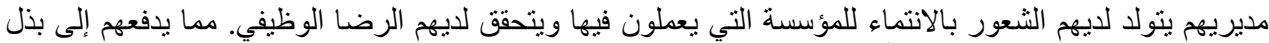

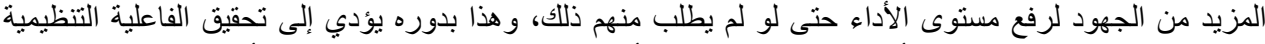

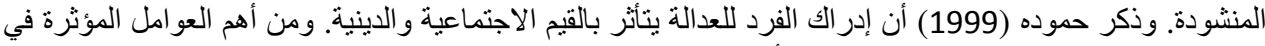

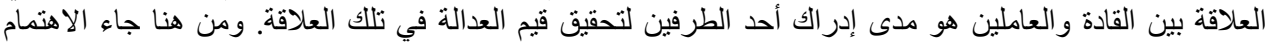

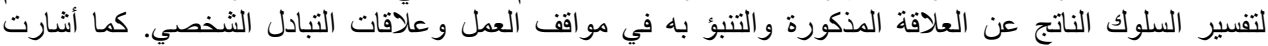

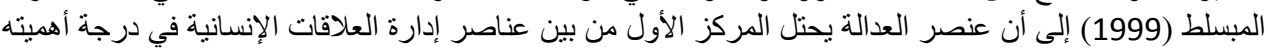

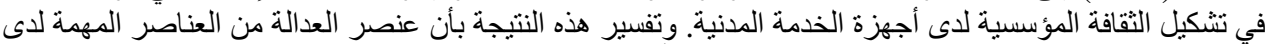

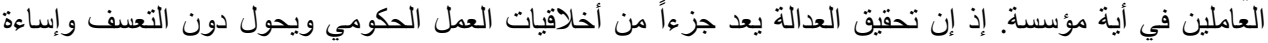

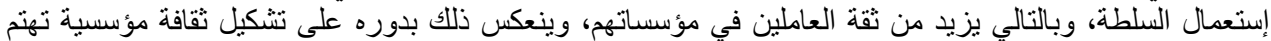
بقيمة العدالة.

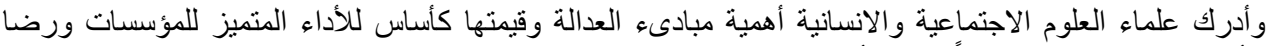

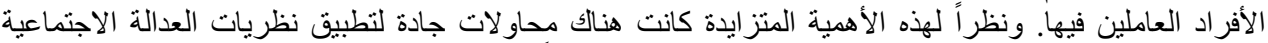

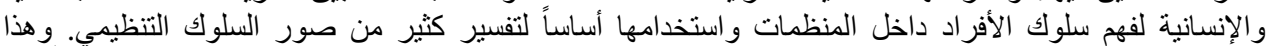

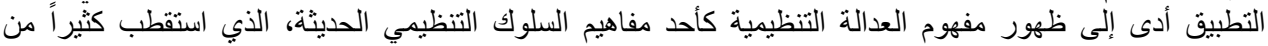

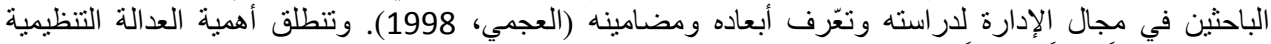

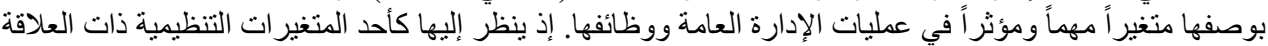

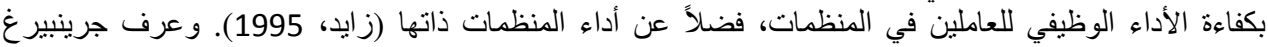

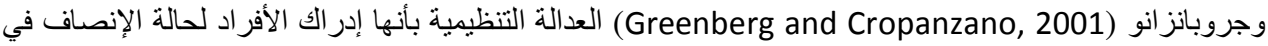

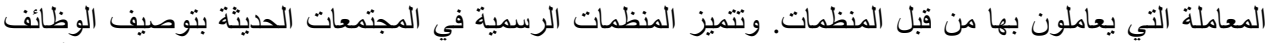

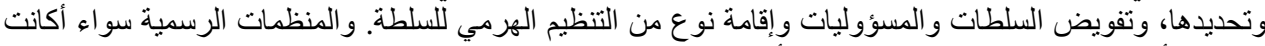

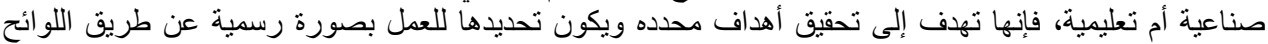

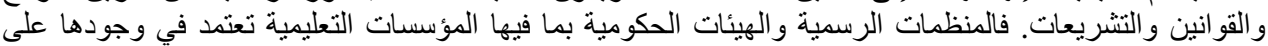

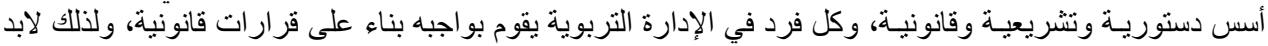

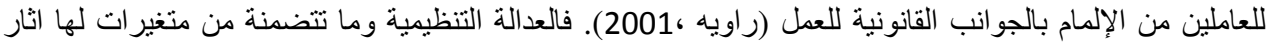

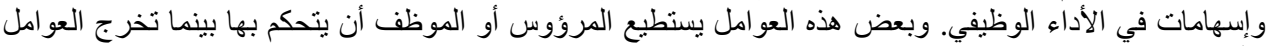

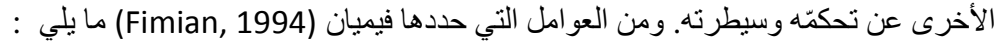

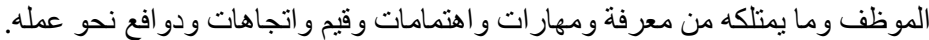

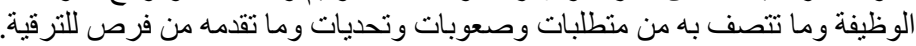

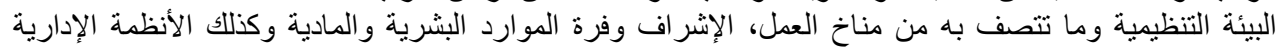
و والهيكل التنظيمي. و أنشار جيبسون (Gibson, 1994) إلى أن هنالك ثلاثة أبعاد مهمه في العمل هي :

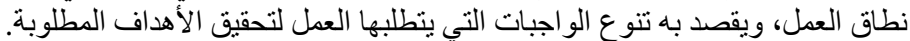

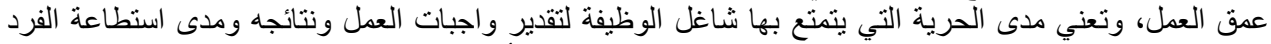

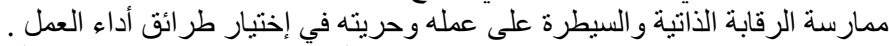

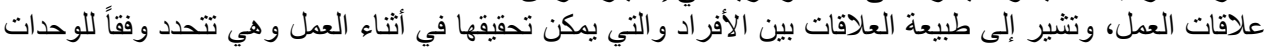

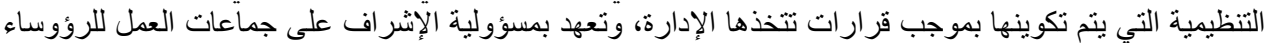
لتنسيق الجهود نحو الأهداف.

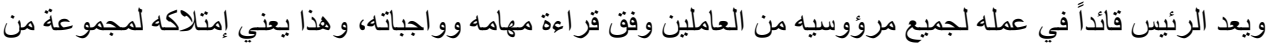

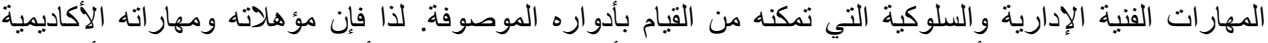

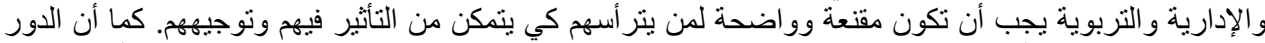

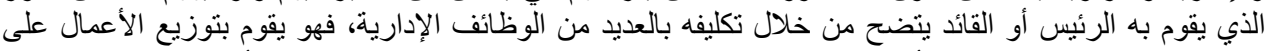

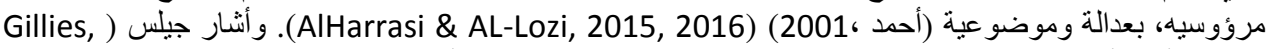

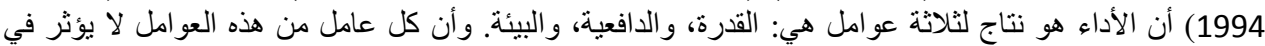

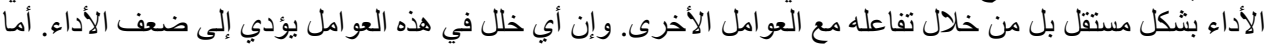


ما يتعلق بأهمية القيام بعملية تقويم الأداء، فإنها تؤدي إلى معرفة واقع الممارسات الأدائية وتعمل على تحفيز الافراد

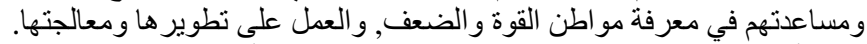

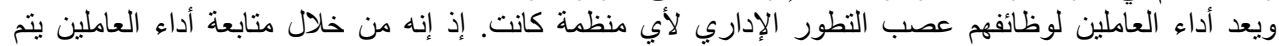

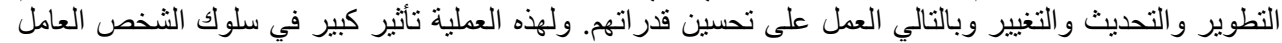

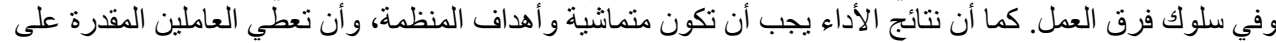

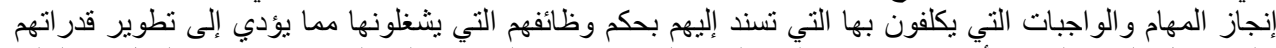

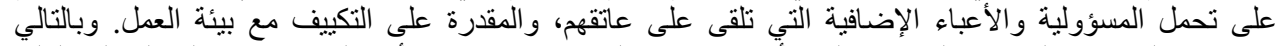

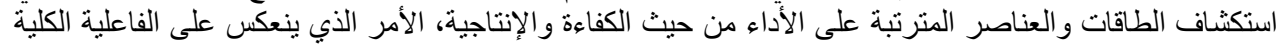

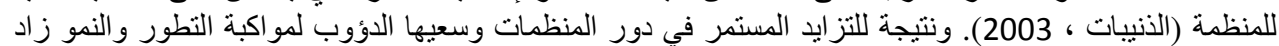

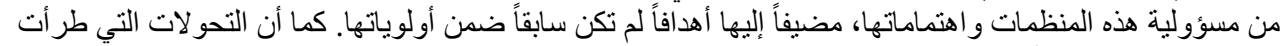

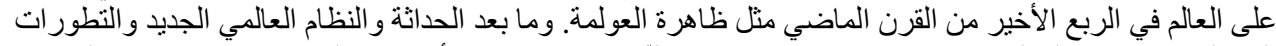

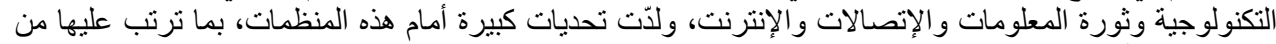

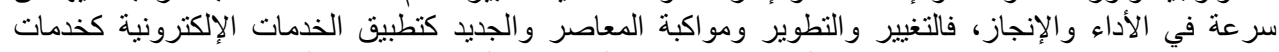

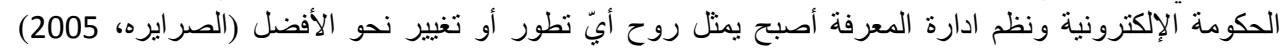
Tarhini et al., 2015; AlHrassi et al., 2016; Almajali et al., 2016; Masa'deh et al., 2018; ) Yassien \& Mufleh, 2017; Alenezi et al., 2017; Alkandari et al., 2017; Khwaldeh et al., .2017; Mikkawi \& Al-Lozi, 2017

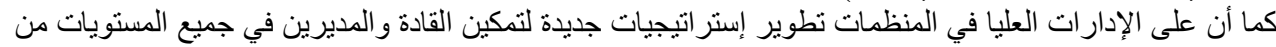

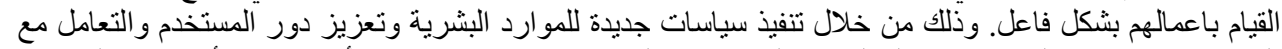

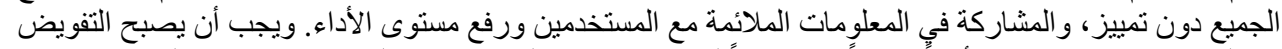

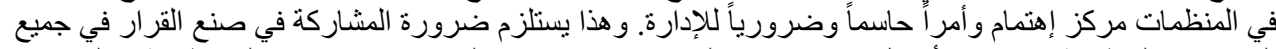

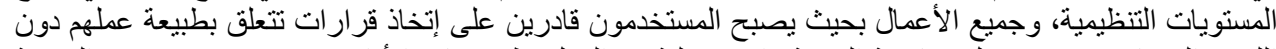

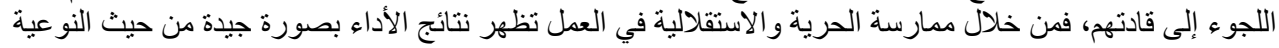
(AL-Lozi, 2002; Arnold \& Pulich, 2003; Obeidat et al., 2017; Abualoush et al., 2018) العساف (2006) أن مفهوم تفويض السلطة يثبر إلى إعطاء أفراد المنظمة الثقة والحرية و المصادر التي تدعم عملهم

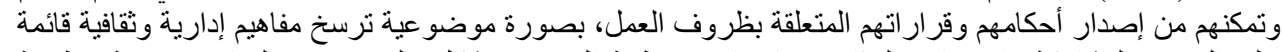

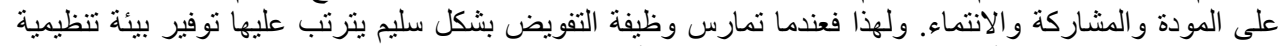

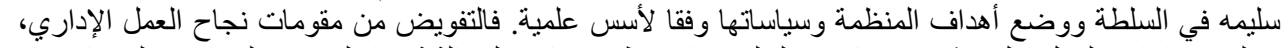

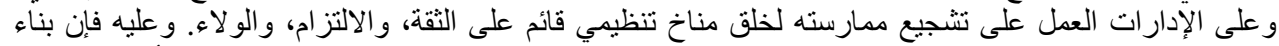

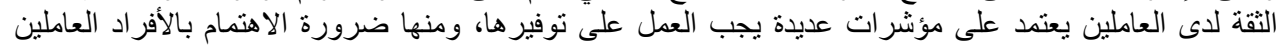

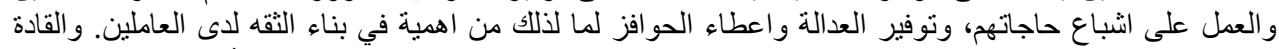

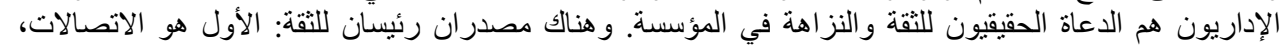

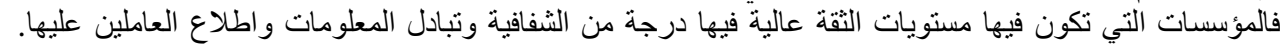

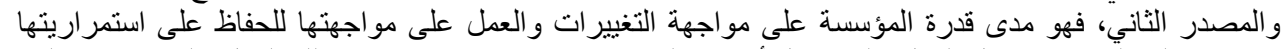

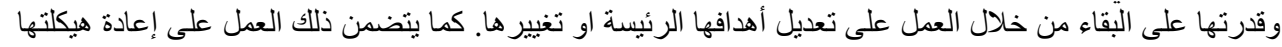

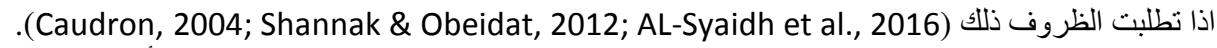

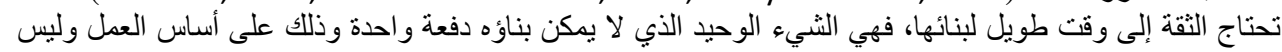

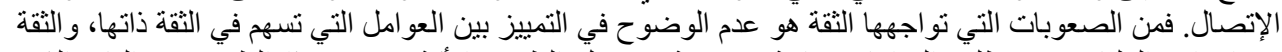

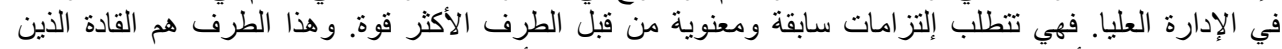

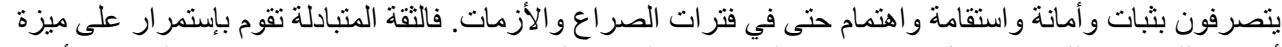

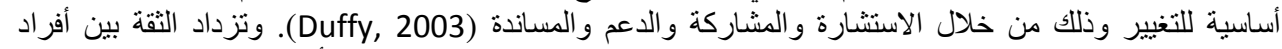

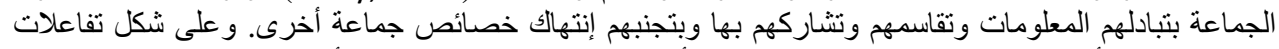

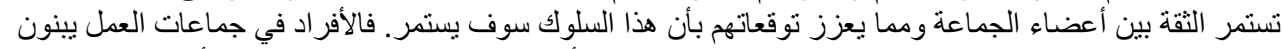

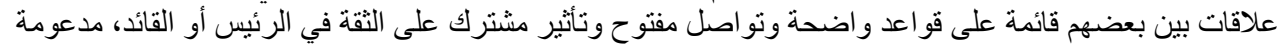

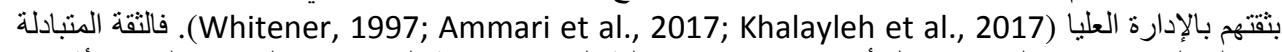

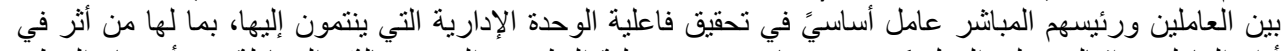

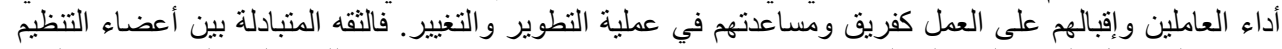

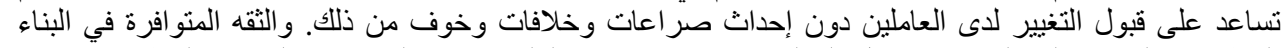
التنظيمي والقائمة على الثفافية وتبادل المعلومات ودعم الإدراة العلياء تعزز الكثير من المفاهيم التنظيمية وتظهر الثين 
القدرات والمواهب الإبداعية في الإدراة. وتعد الثقة عاملاً رئيساً في عملية التطوير والتغيير التنظيمي، والتي تساعد

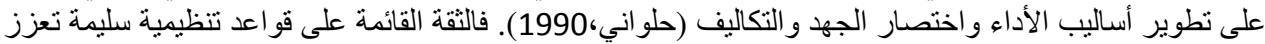

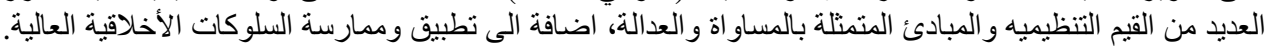

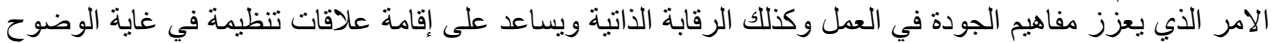

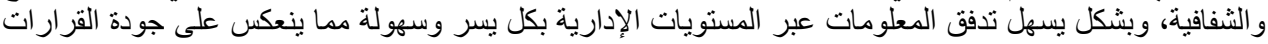

والأداء (Ogilvy, 1995).

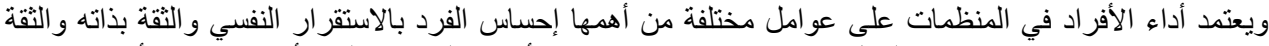

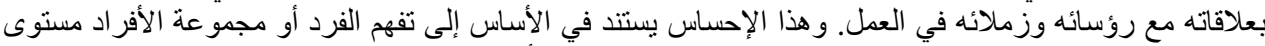

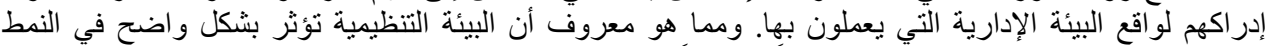

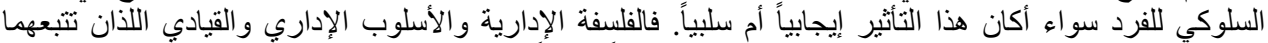

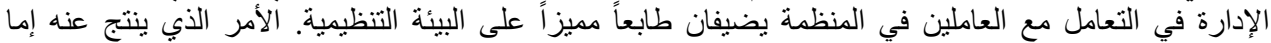

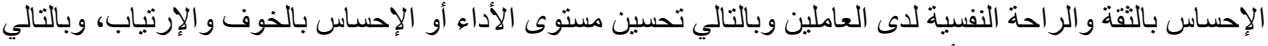

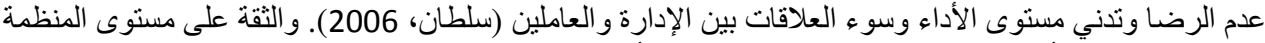

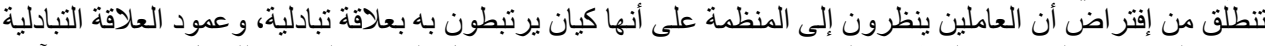

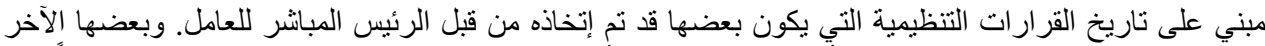

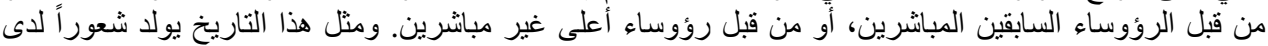

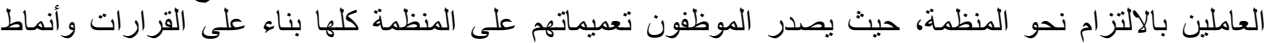

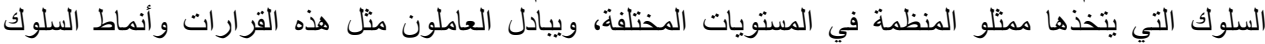

باتجاهات وسلوك تكون موجهة نحو المنظمة نفسها وليس نحو الأفر اد الذين يمثلونها (Wayne et al., 1997).

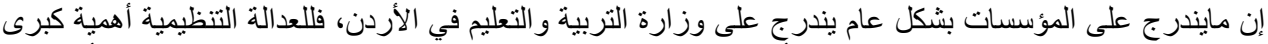

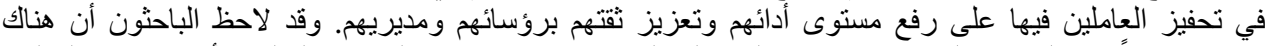

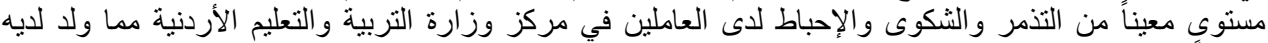

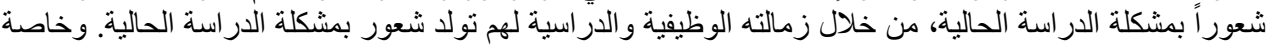

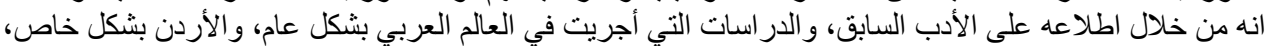

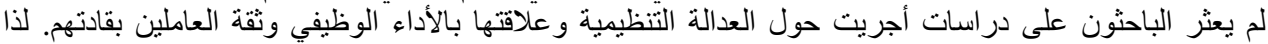

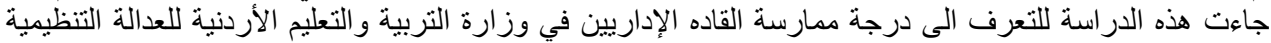
و علاقتها بالأداء الوظيفي للعاملين ونقتهم بقادتهم.

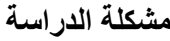

تتحدد مشكلة الدر اسة في تعرّف درجة مالة مارسة القادة الإداريين في وزارة التربية والتعليم الأردنية للعدالة التنظيمية

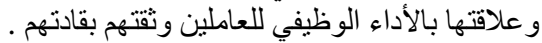
هدف الار اسة وأسئلتها

هدفت الدراسة الى تعرف دراسة دالثة ممارسة القادة الادارين في وزارة التربية والتعليم الاردنية للعدالة التنظيمية و علاقتها

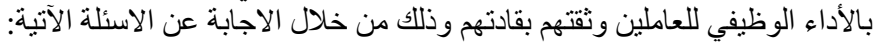

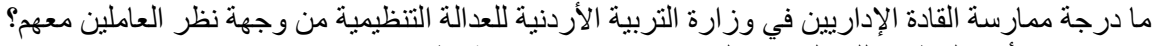

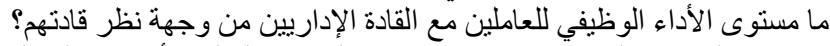

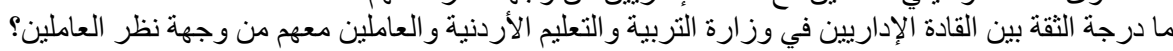

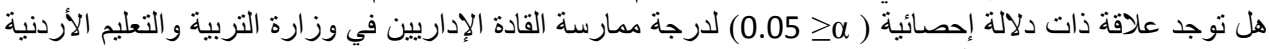

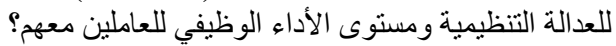

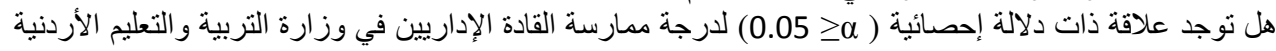

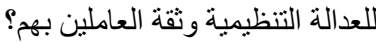

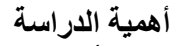

تكمن أهمية الدراسة في أنها تستهدف استطلاع أراء فئة مهمة في المؤسسات التربوية لمفهوم العدالة التنظيمية

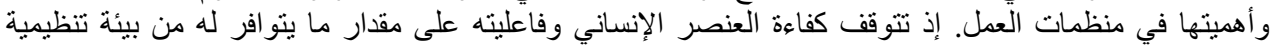

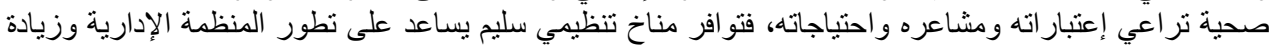

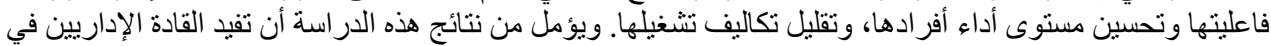

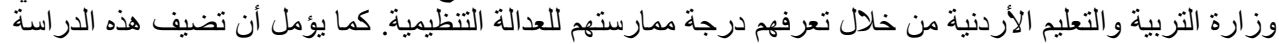

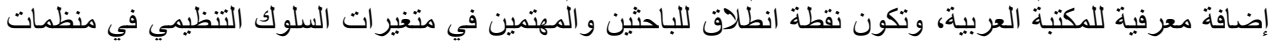

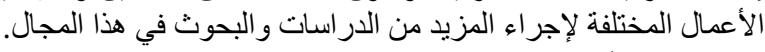
تعريف المصطلحات فيما يأتي تعريف مصطلحات الدمبط اسة : 
ـ القادة الإداريون: عرفهم القريوتي (2000) بأنهم الأفراد الذين يؤثرون على مجمو عة من الأفراد أو جماعة ويكسبون

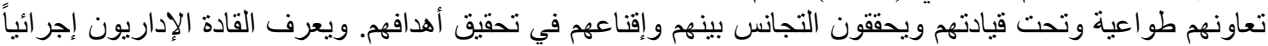

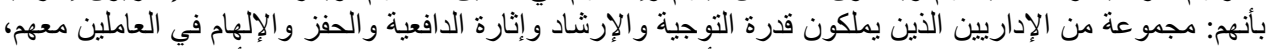

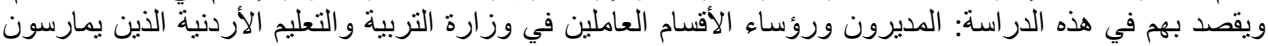
وظائف إدارية .

ـ العدالة التنظيمية: عرفها بايرزو رو (Byars and Rue, 1997) بأنها محصلة الاتفاق بين الجهود المبذولة والعوائد

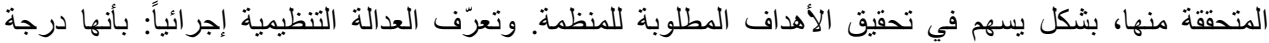

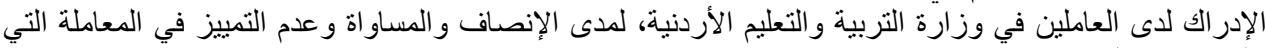
يتلقونها من قبل قادتهم الإداريين.

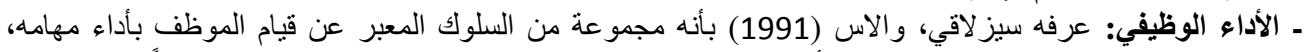

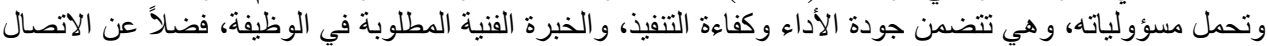

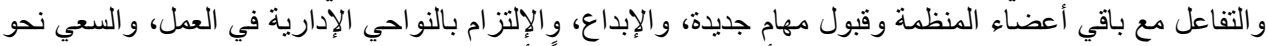

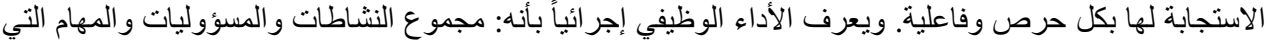

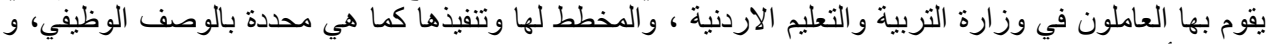

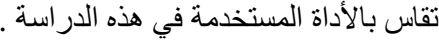

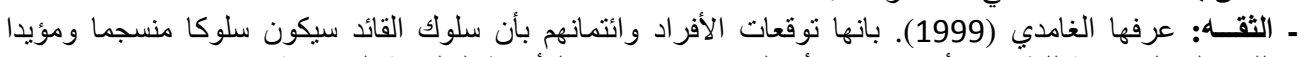

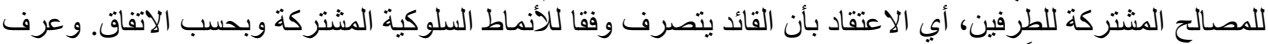

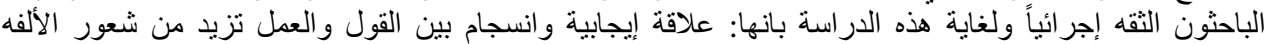

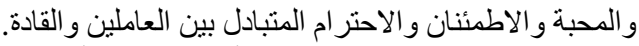

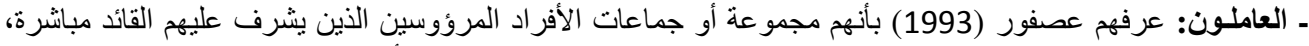

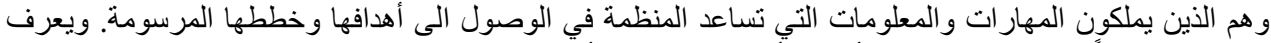

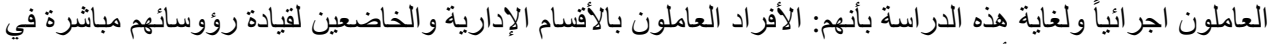
وز وزارة التربية والتعليم الأردنية. حدود الاراسة هذبة ـ اقتصرت هذه الدراسة على القادة التربويين و العاملين معهم في وزارة التربية والتعليم الأردنية (المركز) خلال العام

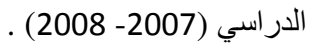
ـ تتحدد نتائج هذه الدراسة بدرجة صدق الأدوات المستخدمة وثباتها. وصدق استجابات أفر اد العينة لها.

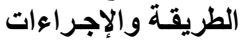

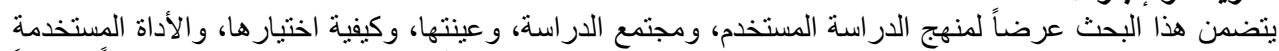

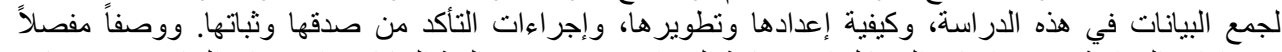

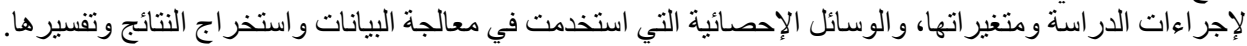

منهج الاراسـة الإنة استخدم الباحثون المنهج الوصفي التحليلي والارتباطي في هذه الدراسة.

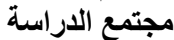
تكون مجتمع الدراسة من جميع مديري الإدارات و المديرين المختصين ورؤساء الأقسام و الموظفين في تلإك الأقسام؛

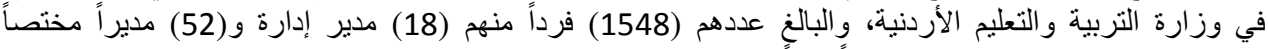

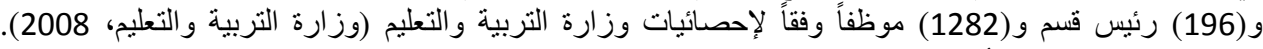

و الجدول (1) يبين توز فئ أفر اد مجتمع الدراسة. الجدول (1). مجتمع الاراسة (عداد العاملين في الإدارات العامة لاى وزارة التربية و التعليم)

\begin{tabular}{|c|c|c|c|c|c|}
\hline موظف & رئيس قسم & مدير مختص & إدارة & الإدارة & 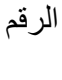 \\
\hline 111 & 14 & 3 & 1 & إدارة الموارد البشرية & 1 \\
\hline 146 & 19 & 3 & 1 & إدارة اللوازم و التزويد & 2 \\
\hline 42 & 7 & 3 & 1 & إدارة التخطيط التربوي & 3 \\
\hline 33 & 11 & 4 & 1 & إدارة الشؤون المالية & 4 \\
\hline 10 & 4 & 2 & 1 & إدارة الشؤون القانونية & 5 \\
\hline 108 & 12 & 4 & 1 & إدارة الأبنية والمشاريع الدولية & 6 \\
\hline 26 & 4 & 2 & 1 & إدارة العلاقات الثقافية و الدولية & 7 \\
\hline
\end{tabular}


Journal of Social Sciences (COES\&RJ-JSS), 7(4), pp.277-302

\begin{tabular}{|c|c|c|c|c|c|}
\hline 33 & 14 & 3 & 1 & إدارة النشاطات التربوية & 8 \\
\hline 38 & 12 & 2 & 1 & إدارة التعليم العام وشؤون الطلبة & 9 \\
\hline 66 & 13 & 3 & 1 & إدارة التعليم المهني و الإنتاج & 10 \\
\hline 44 & 7 & 2 & 1 & إدارة البحث و التطوير التربوي & 11 \\
\hline 157 & 18 & 3 & 1 & إدارة المناهج و الكتب المدرسية & 12 \\
\hline 43 & 9 & 3 & 1 & إدارة تكنولوجيا المعلومات & 13 \\
\hline 41 & 8 & 3 & 1 & مركز الملكة رانيا لتكنولوجيا التعليم & 14 \\
\hline 86 & 11 & 3 & 1 & إدارة التدريب و التأهيل والإشر اف & 15 \\
\hline 128 & 12 & 2 & 1 & إدارة الامتحانات و الاختبار ات & 16 \\
\hline 29 & 8 & 2 & 1 & إدارة الرقابة و التفتيش & 17 \\
\hline 13 & 5 & 1 & 1 & وإلثقافة سر العلجنة الوطنية للتربية & 18 \\
\hline 11 & 2 & 1 & ل لا يوجد & إدارة الإعلام و العلاقات العامة & 19 \\
\hline 106 & 5 & 1 & ل الا يوجد & الديوان العام & 20 \\
\hline 11 & 1 & 2 & لا يوجد & مكتب الوزير & 21 \\
\hline 1282 & 196 & 52 & 18 & (21 ) إدارة & المجمو \\
\hline
\end{tabular}

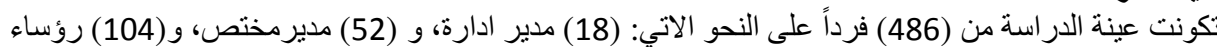

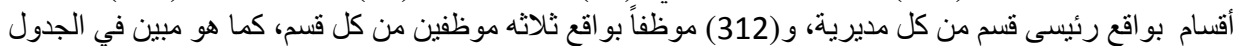

الجدول (2). توزيع أفراد عينة الدراسة حسب متغيرات الاراسة

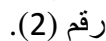

\begin{tabular}{|c|c|c|c|c|c|}
\hline موظف & رئيس قسم & مدير مختص & مدير إدارة & الإلدارة & الرقم \\
\hline 18 & 6 & 3 & 1 & إدارة الموارد البشرية & 1 \\
\hline 18 & 6 & 3 & 1 & إدارة اللوازم و التزويد & 2 \\
\hline 18 & 6 & 3 & 1 & إدارة التخطيط التربوي & 3 \\
\hline 24 & 8 & 4 & 1 & إدارة الثؤون المالية & 4 \\
\hline 12 & 4 & 2 & 1 & إدارة الثؤون القانونية & 5 \\
\hline 24 & 8 & 4 & 1 & إدارة الأبنية و المشاريع الدولية & 6 \\
\hline 12 & 4 & 2 & 1 & إدارة العلاقات الثقافية والدولية & 7 \\
\hline 18 & 6 & 3 & 1 & إدارة النشاطات التربوية & 8 \\
\hline 12 & 4 & 2 & 1 & إدارة التعليم العام وشؤون الطلبة & 9 \\
\hline 18 & 6 & 3 & 1 & إدارة التعليم المهني والإنتاج & 10 \\
\hline 12 & 4 & 2 & 1 & إدارة البحث والتطوير التربوي & 11 \\
\hline 18 & 6 & 3 & 1 & إدارة الدناهج و الكتب المدرسية & 12 \\
\hline 18 & 6 & 3 & 1 & إدارة تكنولوجيا المعلومات & 13 \\
\hline 18 & 6 & 3 & 1 & التعليم الملكة رانبا لتكنولوجيا & 14 \\
\hline 18 & 6 & 3 & 1 & وإدارة التندريب و التأهيل & 15 \\
\hline 12 & 4 & 2 & 1 & إدارة الامتحانات والاختبارات & 16 \\
\hline 12 & 4 & 2 & 1 & إدارة الرقابة و التفتيش & 17 \\
\hline 6 & 2 & 1 & 1 & 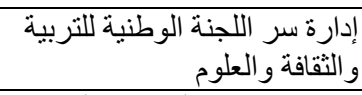 & 18 \\
\hline 6 & 2 & 1 & لا يوجد & إدارة الإعلام و العلاقات العامة & 19 \\
\hline 6 & 2 & 1 & لا لايوجد & الديوان العام & 20 \\
\hline
\end{tabular}


The Practicing Degree of Organizational Justice .......

\begin{tabular}{|c|c|c|c|c|c|}
\hline 6 & 2 & 2 & لا يوجد & مكتب الوزير & 21 \\
\hline 312 & 104 & 52 & 18 & (21 ) إدارة & \\
\hline
\end{tabular}

أدوات الدراسة

لتحقيق هدف الدر اسة المتمثل في الكثف عن درجة ممارسة القادة الإداريين في وزارة التربية و التعليم الأردنية للعدالة

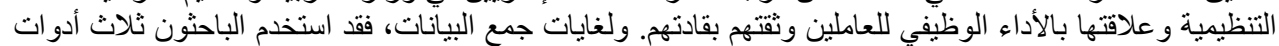

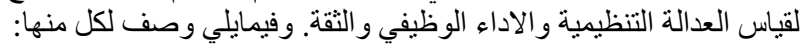
القسم الأول: استبانة العدالة التنظيمية.

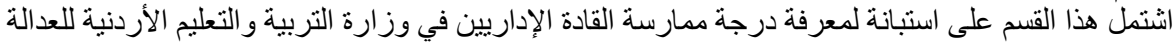

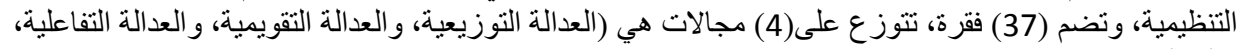

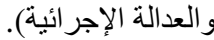
القسم الثاني: استبانة الأداء الوانة) الوظيفي. اشتمل هذا القسم على استبانة لقياس مستوى الأنسف الأداء الوظيفي للمرؤوسين في الوحدات الإدارية في وزارة التربية و التعليم الأردنية من وجهة نظر القادة الإداريين لتلك الوحدات. وتكونت الأنس الاستبانة من (18) فقرة. القسم الثالث: استبانة الثقة.

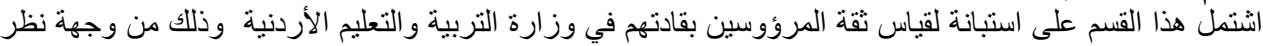
المرؤوسين في الوحدات الإدارية في وزارة التربية والتعليم الأردنية ، وتكونت الإستبانة من (24) فقرة.

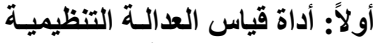
قام الباحثون بإعداد أداة قياس العدالة التبادة التظيمية بعد استعر اض الأدب النظري المتعلق بالموضوع، بعد الاطلاع على (2005)

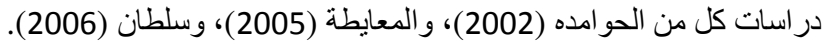

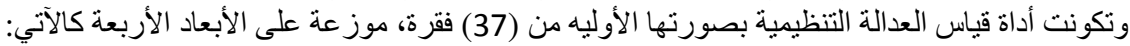

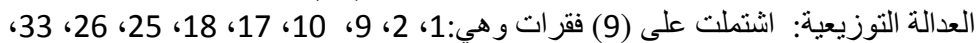

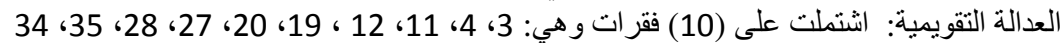

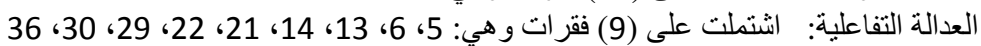

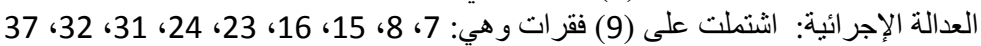

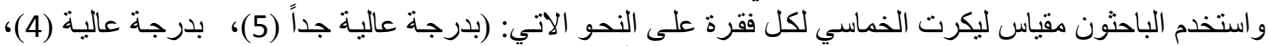

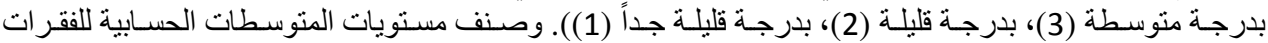

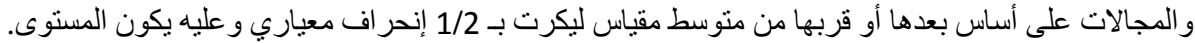

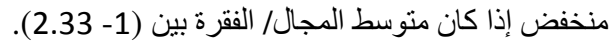

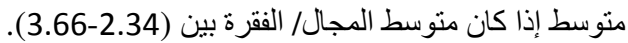

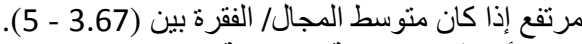
صدق أداة قياس العدان منتة التنظيمية للتأكد من دقة الترجمة الترة والسلامة اللغوية لفقر ات استبانة العدالة التنظيمية، فقد تم عرضها على عدد من المتخصصين.

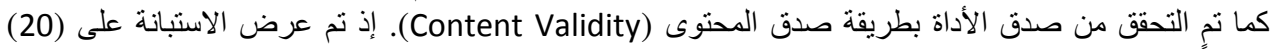

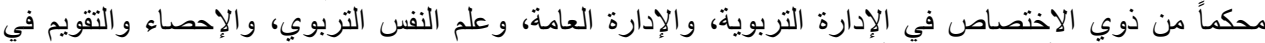

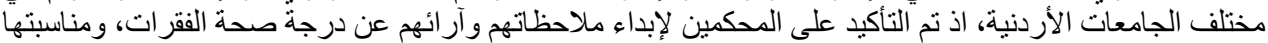

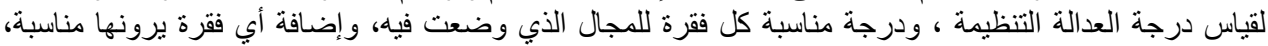

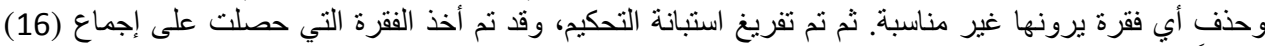

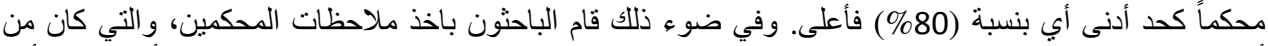

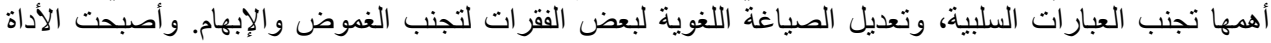
بصورتها النهائية تتكون من (37) فقرة موزعة الهيار على المجالات الأربعة الأساسية، بحيث بقيت المجالات الأربعة على الألى حالها (37) فقرة.

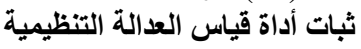

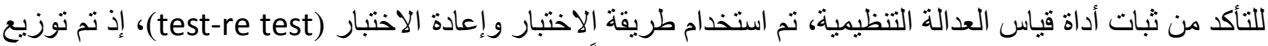

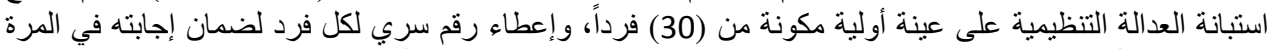

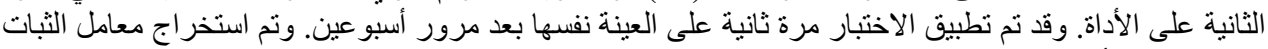

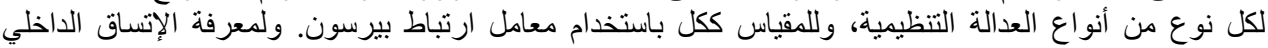


Journal of Social Sciences (COES\&RJ-JSS), 7(4), pp.277-302

لللقرات تم استخدام كرومباخ ألفا. والجدول (3) يبين ثبات أداة العدالة التنظيمية بطريقة الاختبار وإعادة الاختبار

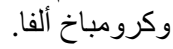

الجدول (3). معامل ارتباط بيرسون وكرونباخ ألفا لمجالات أداة قياس العدالة التنظيمية

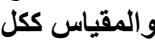

\begin{tabular}{|c|c|c|c|}
\hline كرونباخ ألفا & معامل ارتباط بيرسون & المجال & الأداة \\
\hline 0.89 & 0.86 & العدالة التوزيعية & \multirow{5}{*}{ العدالة التنظيمية } \\
\hline 0.93 & 0.92 & العدالة التقويمية & \\
\hline 0.93 & 0.80 & العدالة التفاعلية & \\
\hline 0.93 & 0.90 & العدالة الإجر ائية & \\
\hline 0.97 & 0.95 & الكلي للادداة & \\
\hline
\end{tabular}

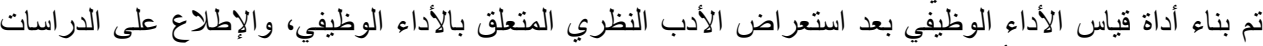

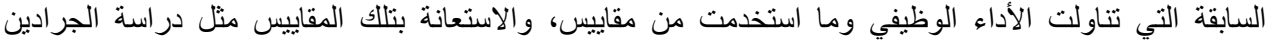

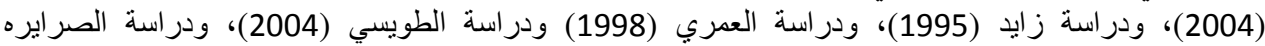

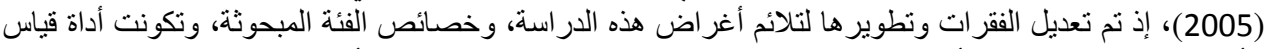

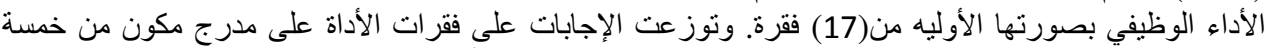

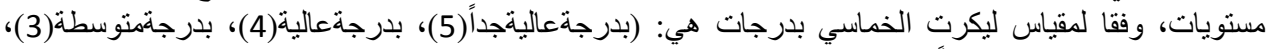

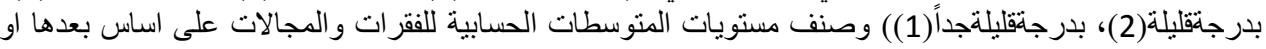

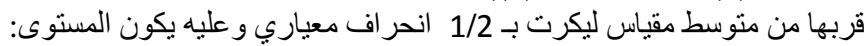

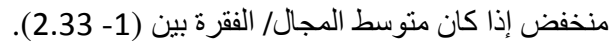

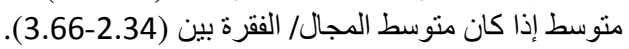
مرتفع إذا كان متوسط المجال/ الفقرة بين (3.67 - 5).

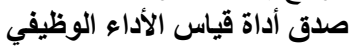

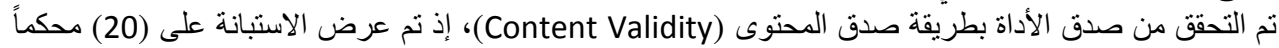

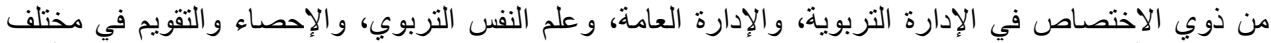

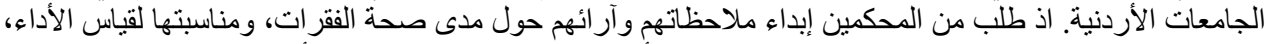

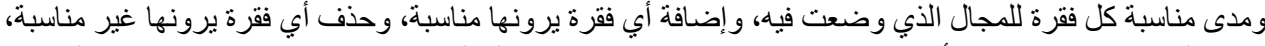

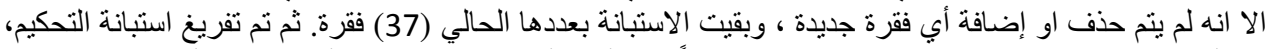

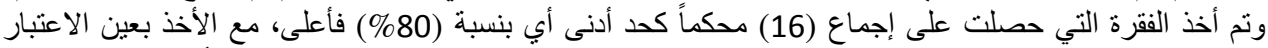

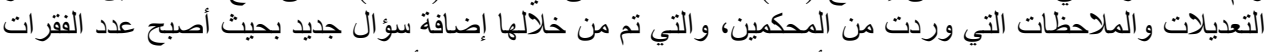

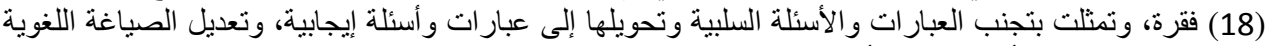

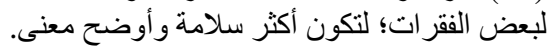

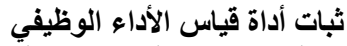

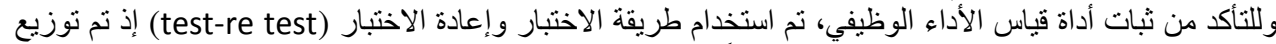

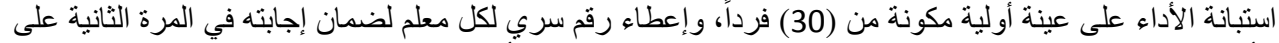
الأداة. وقد نم تطبيق الاختبار مرة ثانية على العينة نفسها بعد مرور أسبو عين. ثم تم حساب معلى معدل الثبان الثبات باستخدام

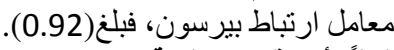

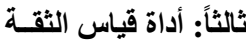

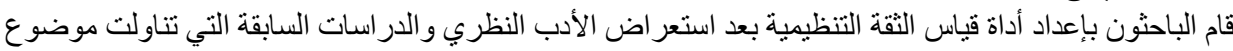

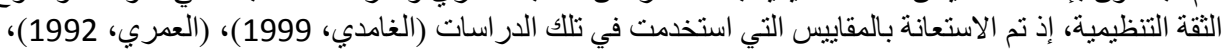

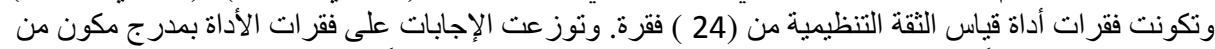

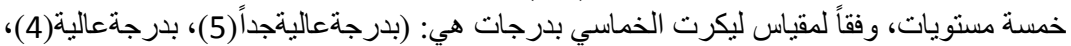

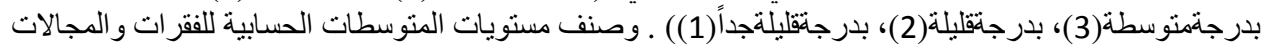

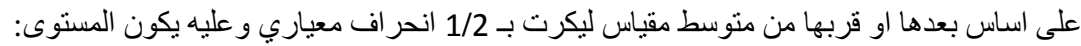

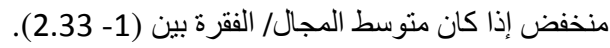
متوسط إذا كان متوسط الدجال/ الفقرة بين (2.34-3.66). 

صرتفع إذا كان متوسط المجال/ الفقرة بين (3.67 - 5). للتأكد من دقة الدياست الترجة والسلامة اللغوية لفقرات استبانة الثقة، فقد ثم عرضها على عدد من المترجمين المتخصصين.

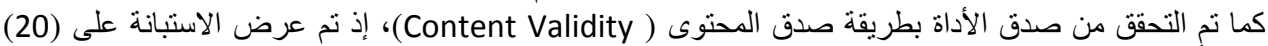

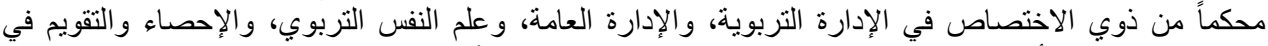

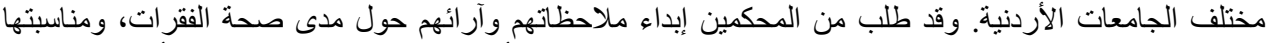

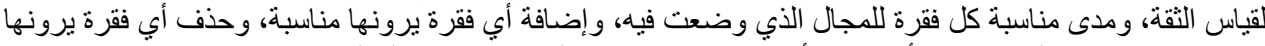

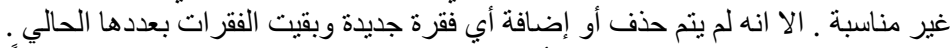
ثم تم تفريغ استبانة التحكيم، وقد نتم أخذ الفقرة التي حصلت على على إجماع (16) محكماً كحد أدنى أي بنسبة (80)

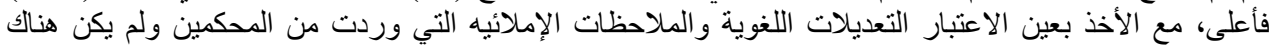

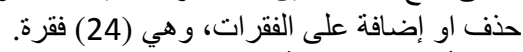

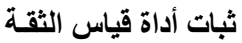

وللتأكد من ثبات أداة قياس التقة، فقد تم استخدام طريقة الاختبار و إعادة الاختبار (test-re test)، إذ إذ تم توزيع استبانة

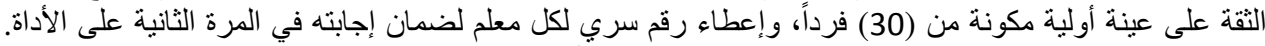

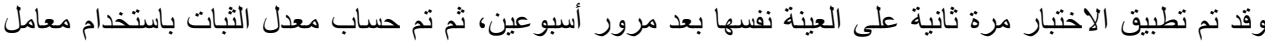
ارتباط بيرسون، وقد بلغ معامل ثبات الأداة (0.98).

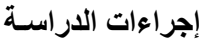

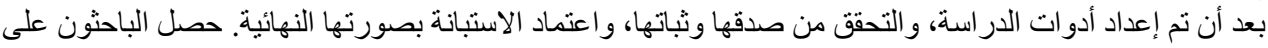

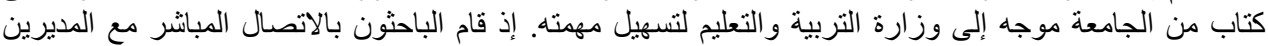

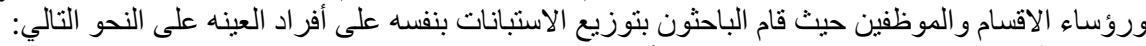

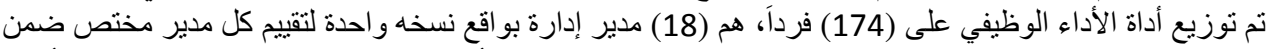

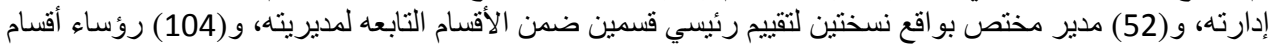

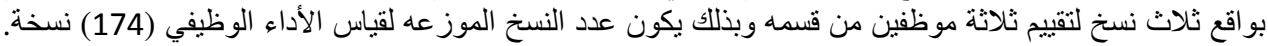

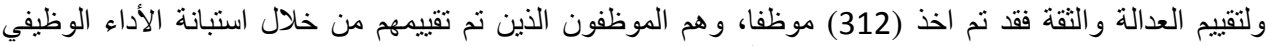

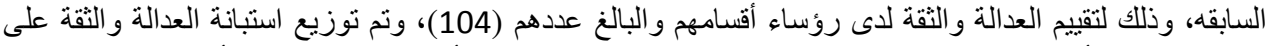

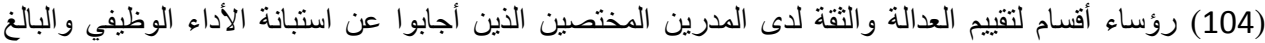

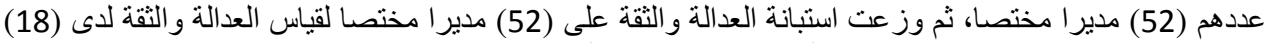

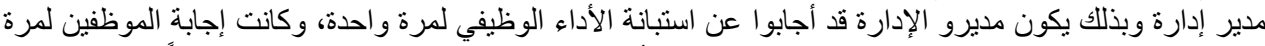

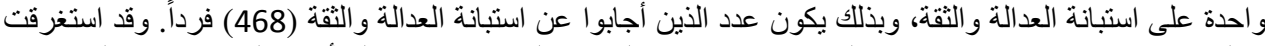

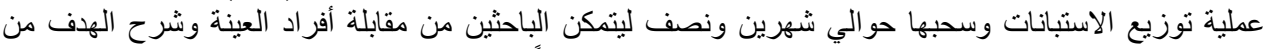

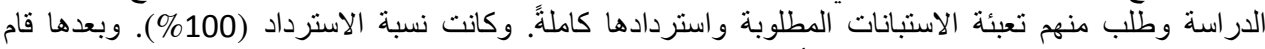

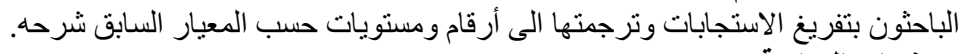

متغيرات الاراسة

تضمنت هذه الدر اسة متغيراً مستقلاً واحداً هو العدالة التنظيمية للقادة الإداريين. كما تضمنت الدراسة متغيرين تابعين هما: الأداء الوظيفي للعاملين، وثنة العانة العاملين بقادتهم.

المعالجات الإحصائية الإدية

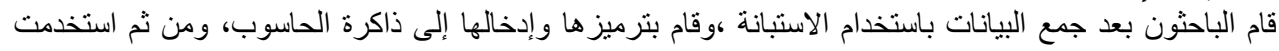

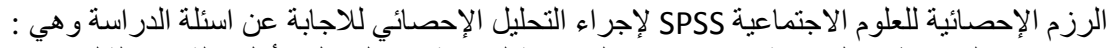

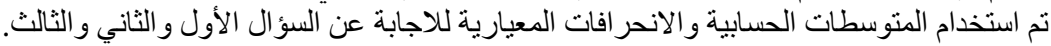

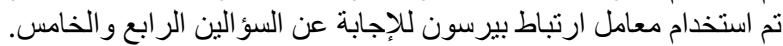

نتائج الدراسـة

هدفت هذه الدراسة إلى تعرف درجة الألهاء ممارسة القادة الإداريين في وزارة التربية والتعليم الأردنية للعدالة التنظيمية

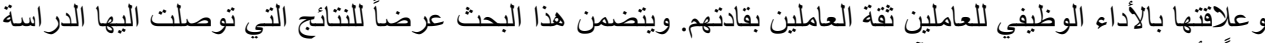
وفقاً لأسئلتها وذللك على الألى النحو الآتي:

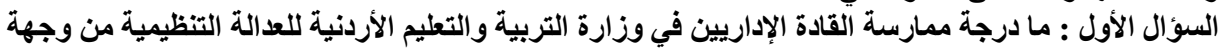

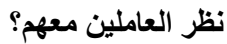

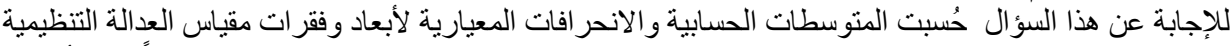

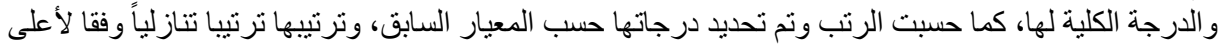


منوسط حسابي للفقرة. وقد تبين أن درجة ممارسة القادة الإداريين في وز ارة التربية والتعليم الأردنية للعدالة التنظيمية

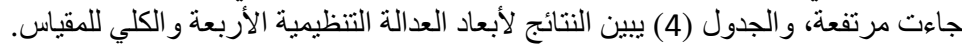

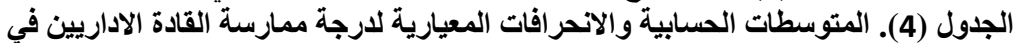
وزارة التربية والتعليم وفقا لأبعاد العدالة التنظيمية من وجهة التية نظر العاملين معهم مرتبة تنازليًاً

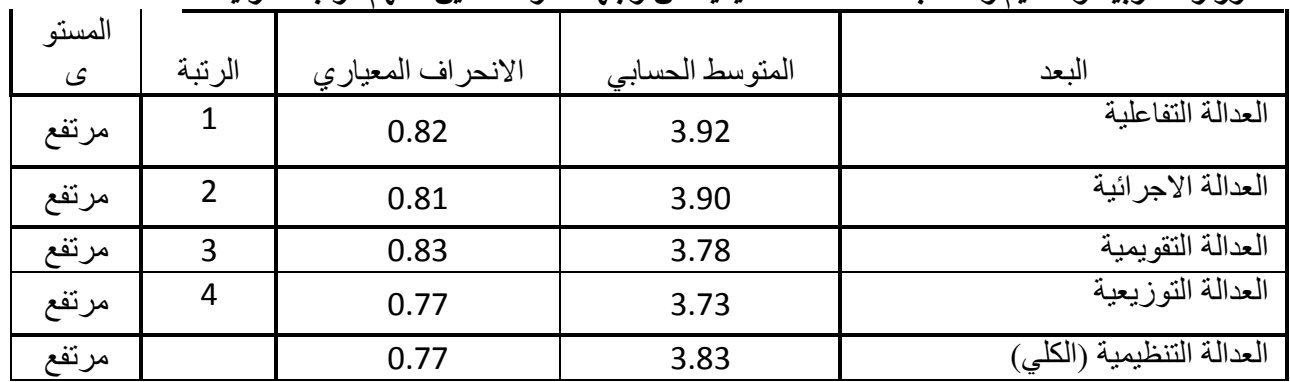

يبين الجدول (4) أن المتوسط الحسابي الكلي لدرجة ممارسة القادة الإداريين للعدالة التنظيمية من وجهة نظر التهر العاملين

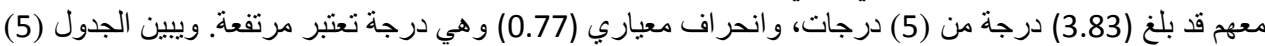

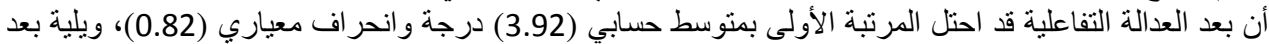

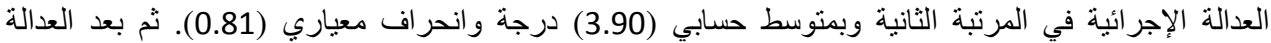

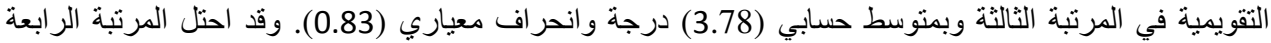
و الأخيرة بعد العدالة التوزيعية بمتو سط حسابي (3.73) درجة و انحر اف معياري (0.77). ويتبين من ذلك ألكان أن درجات

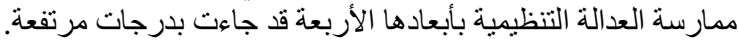

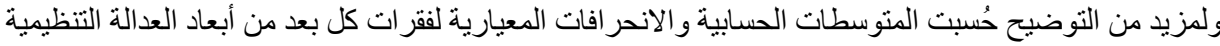

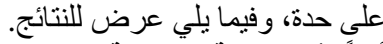
أولاً: بُعد العدالة التفاعلية.

تم حساب المتوسطات العسابية والانحة العابة العات المعيارية لجميع فقر ات بعد العدالة التفاعلية وقد تم ترتيبها تنازليا وفقا

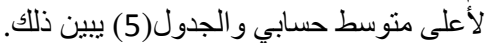

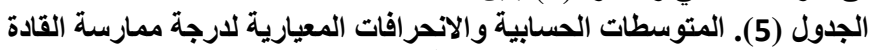

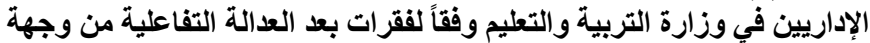
نظر العاملين معهم مرتبة تنازليا

\begin{tabular}{|c|c|c|c|c|c|}
\hline المستوى & 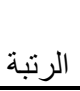 & الانحر افياري & المسابي & فقرات بعد العدالة التفاعلية & الرقم \\
\hline 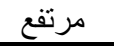 & 1 & 0.96 & 4.09 & يتبنى المدير علاقات طيبة مع الجميع. & 29 \\
\hline 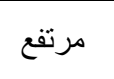 & 2 & 1.00 & 4.07 & العاملين. المدير على العمل بروح الفريق بين & 21 \\
\hline 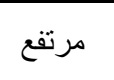 & 3 & 1.01 & 3.98 & 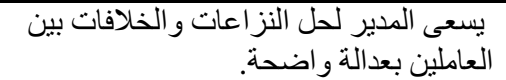 & 22 \\
\hline مرتفع & 4 & 0.98 & 3.90 & بقأنم المدير تبرير أ مقنعاً للقر ارات التي اتخذت & 30 \\
\hline 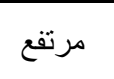 & 5 & 1.03 & 3.87 & المتعلقة بعملي. النقائج المترتبة على القرارات & 13 \\
\hline 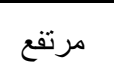 & 6 & 1.01 & 3.86 & المدير بوضوح أية قرارات تتخذ بشأن & 36 \\
\hline 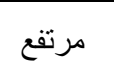 & 6 & 1.03 & 3.86 & لية المدوضير في القرار ات المتعلقة بعدلي & 6 \\
\hline 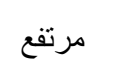 & 8 & 1.07 & 3.85 & اتخاذ قر ار اتدير ظعلقوفة بعملي. وحاجاتي الخاصة عند & 5 \\
\hline 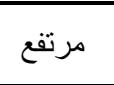 & 9 & 1.07 & 3.83 & اتخاذ التي المدار حقو الخاصي وو اجباتي الوظيفية عند & 14 \\
\hline مرتفع & - & 0.82 & 3.92 & العدالة التفاعلية ( الكلي) & \\
\hline
\end{tabular}




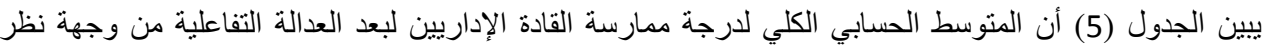

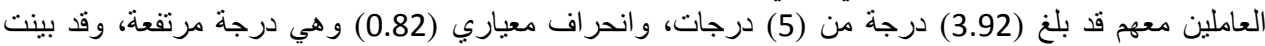

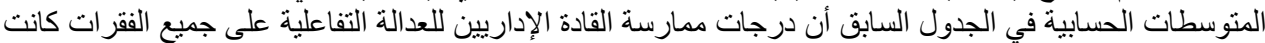

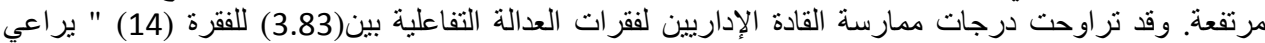

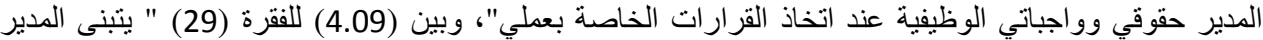

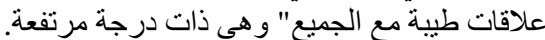
ثانياً: بُعد العدالة طبع الإجرائية.

تم حساب المتوسطات الحسابية والانحر افات المعيارية لجميع فقرات بعد العدالة الإجر ائية وقد تم ترتيبها تنازليا وفقا

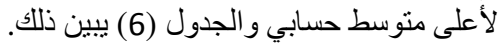
الجدول (6). المتوسطات الحسابية والانحرافات المعيارية لارجة ممارسة القادة الإداريين في وزارة التربية والتعليم التئيم

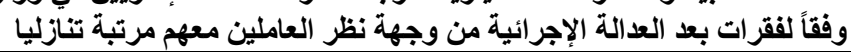

\begin{tabular}{|c|c|c|c|c|c|}
\hline 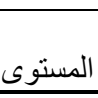 & 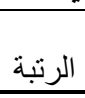 & 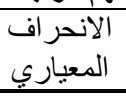 & ال الحتوسطي & فقر ات بعد العدالة الاجر ائية & 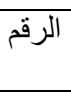 \\
\hline مرتفع & 1 & 0.98 & 4.04 & يوضح المدير للعاملين انطباعاته عن سير العمل. & 37 \\
\hline 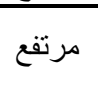 & 2 & 0.93 & 4.00 & عنها عند الطلبر. القرارات ويزود العاملين بمعلومات & 23 \\
\hline 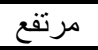 & 3 & 1.04 & 3.94 & يوضح المدير لجميع العاملين حقوقهم وواجباتهم. & 8 \\
\hline 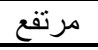 & 4 & 0.95 & 3.93 & يحاسب المدير العاملين على مخالفة التعليمات بعدالة. & 32 \\
\hline 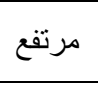 & 5 & 0.98 & 3.89 & 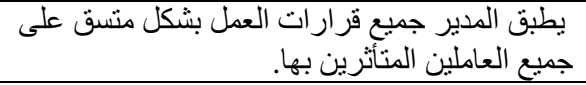 & 24 \\
\hline 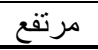 & 6 & 1.07 & 3.88 & يتخذ المدير قرار ات العمل بدون تحيز. & 7 \\
\hline 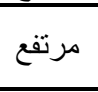 & 6 & 1.04 & 3.88 & قرار يجمع المدير معلومات بقات دقيقة وكاملة قبل اتخاذ & 16 \\
\hline 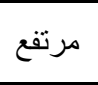 & 8 & 1.00 & 3.82 & يتخذهاح المدير للعاملين استئناف قرارات العمل التي & 31 \\
\hline 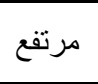 & 9 & 1.09 & 3.79 & 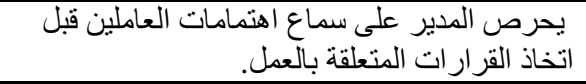 & 15 \\
\hline 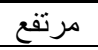 & - & 0.81 & 3.90 & العدالة الاجر ائية ( الكلي) & \\
\hline
\end{tabular}

بلغت المتوسطات الحسابية لارجة ممارسة القادة الإداريين للعدالة الإجرائية من وجهة نظر العاملين معهمة (3.91)

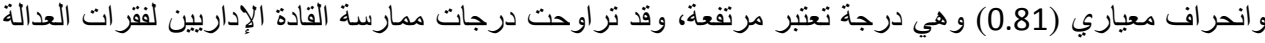

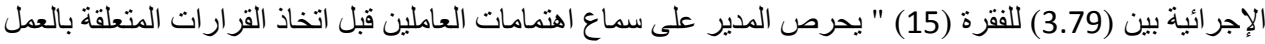

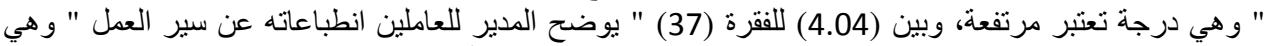

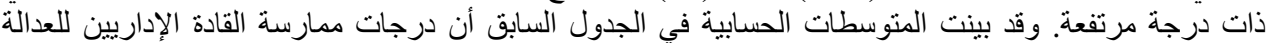

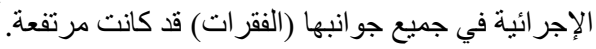

ثُالثاً: بُعد العدالة التقويمية.

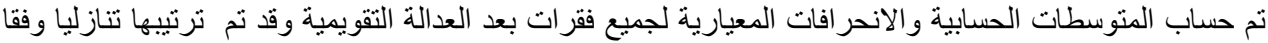
لأعلى متوسط حسابي و الجدول (7) يبين ذلك.

الجدول (7). المتوسطات الحسابية والاتحر افات المعيارية لارجة ممارسة القادة

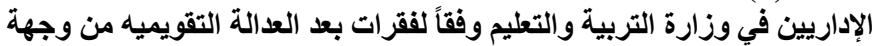
نظر العاملين معهم مرتبة تنازليا

\begin{tabular}{|c|c|c|c|c|c|}
\hline المستوى & 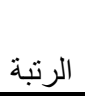 & المعياري & الحسابي & فقرات بعد العدالة التقويمية & الرقم \\
\hline مرتفع & 1 & 1.03 & 4.04 & يهذف المدير من تقييم الأداء رفع إنتاجية & 27 \\
\hline
\end{tabular}


Journal of Social Sciences (COES\&RJ-JSS), 7(4), pp.277-302

\begin{tabular}{|c|c|c|c|c|c|}
\hline \multirow[b]{2}{*}{ المستوى } & \multirow[b]{2}{*}{ الرتبة } & \multicolumn{4}{|c|}{ 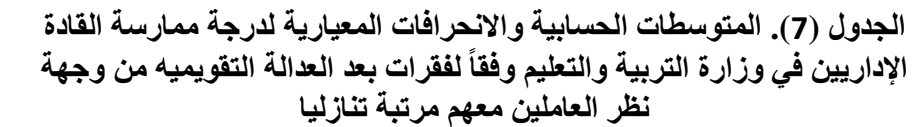 } \\
\hline & & 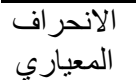 & الحسابي & فقرات بعد العدالة التقويمية & 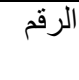 \\
\hline & & & & وتطوير العمل. & \\
\hline مرتفع & 2 & 0.99 & 3.91 & يشجعني المدير على التقييم الذاتي لأدائي. & 34 \\
\hline 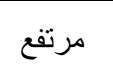 & 2 & 1.01 & 3.91 & الضعاعدني تقييم المدير على معرفة أوجئ أوجي. & 28 \\
\hline 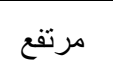 & 4 & 1.00 & 3.84 & يستخداً لتقييم العدير معايير و اضحة ومعروفة & 35 \\
\hline 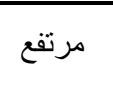 & 5 & 1.06 & 3.83 & 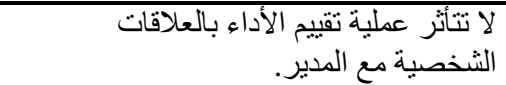 & 19 \\
\hline 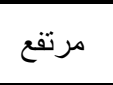 & 6 & 1.03 & 3.75 & التقيقم مسبقاً. بإطلاع العاملين على معايير & 11 \\
\hline مرتفع & 6 & 1.06 & 3.75 & يطن العدالة. المدير معايير تقييم الأداء بدرجة عالية & 4 \\
\hline مرتفع & 8 & 1.05 & 3.67 & نتائج التقييم المدير فرصة العادل. للعاملين للتظلم بشأن & 12 \\
\hline متوسط & 9 & 1.03 & 3.65 & العُعد البر امج التّربينة بناءً على تقييم أداء & 20 \\
\hline متوسط & 10 & 1.14 & 3.53 & يقوم المدير بمكافأة العاملين وفقاً لأدائهم. & 3 \\
\hline مرتفع & - & 0.83 & 3.78 & العدالة التقويمية ( الكلي) & \\
\hline
\end{tabular}

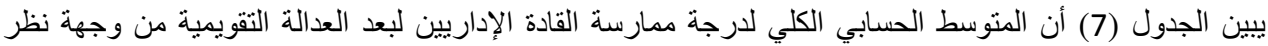

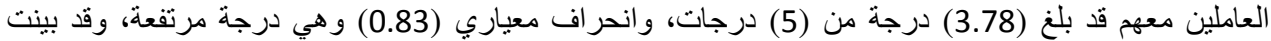

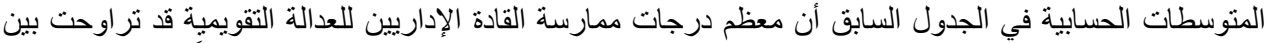

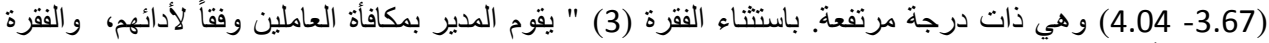

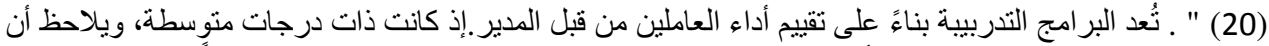

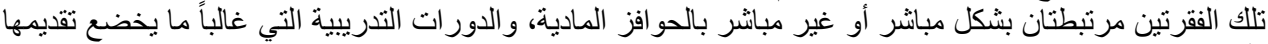

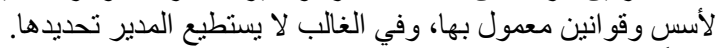
رابعاً: بثعد العدالة التوزيعية. تم حساب المتوسطات الحسابية والانحر افات المعيارية لجميع فقرات بعد العدالة التوزيعية وقد تم ترتيبها تتازليا وفقا

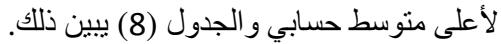

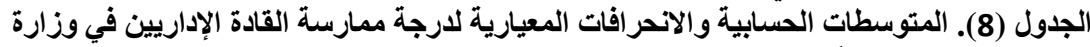

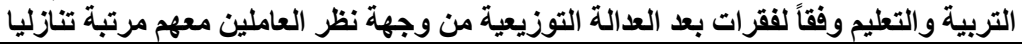

\begin{tabular}{|c|c|c|c|c|c|}
\hline 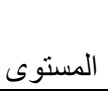 & 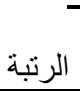 & الانحر اف ال المعياري & الحسابي & فقر ات بعد العدالة التوزيعية & الرقم \\
\hline 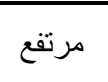 & 1 & 1.00 & 3.97 & العدالة. المدير باستمر ار لتحقيق درجة عالية من & 33 \\
\hline مرتفع & 2 & 0.94 & 3.91 & أعتقد أن الصلاحيات و المسؤوليات الموكلة إلي & 17 \\
\hline مرتفع & 3 & 0.94 & 3.89 & أعنقد أن جدول عملي يتناسب مع وقتي. & 25 \\
\hline مرتفع & 3 & 1.01 & 3.89 & يوزِ المدير العمل بين العاملين توزيعاً عادلاً. & 26 \\
\hline مرتفع & 5 & 1.14 & 3.81 & يوزع المدير العمل الإضافي بعدالة. & 9 \\
\hline مرتفع & 6 & 1.00 & 3.80 & يفوض المدير بعض صلاحياته للعاملين. & 2 \\
\hline مرتفع & 7 & 1.04 & 3.75 & أعتقد أن عبء العمل الذي أقوم به مناسب تماماً. & 10 \\
\hline متوسط & 8 & 1.15 & 3.40 & أثشعر أن المكافآت التي احصل عليها عادلة. & 18 \\
\hline
\end{tabular}




\begin{tabular}{|c|c|c|c|c|c|}
\hline متوسط & 9 & 1.29 & 3.23 & أعتقد أن مستوى الأجر الذي أحصل عليه عادلاً. & 1 \\
\hline مرتفع & - & 0.77 & 3.73 & العدالة التوزيعية (الكلي) & \\
\hline
\end{tabular}

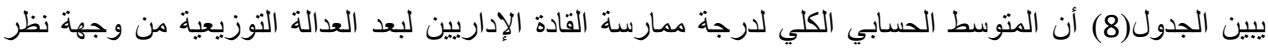

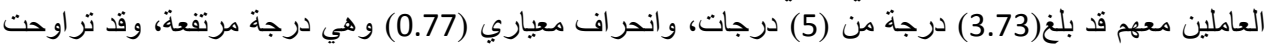

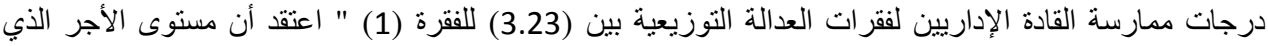

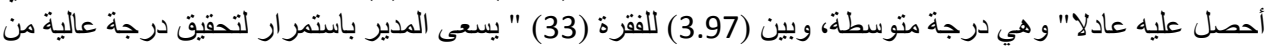

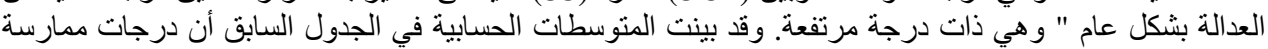

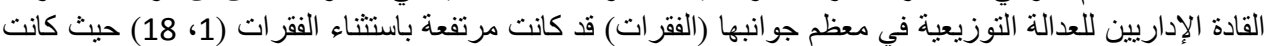

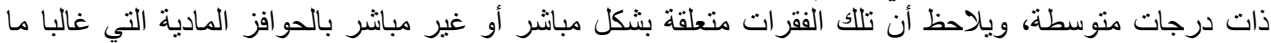

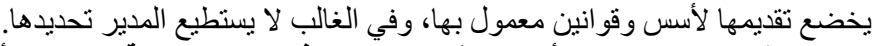

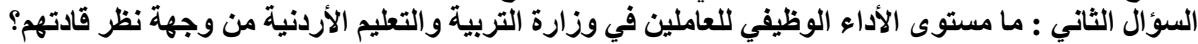

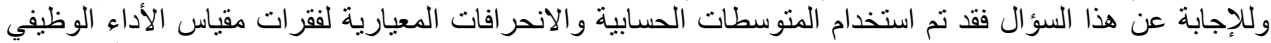

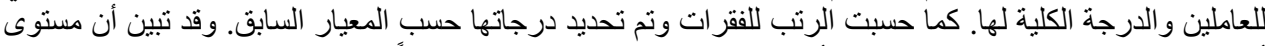

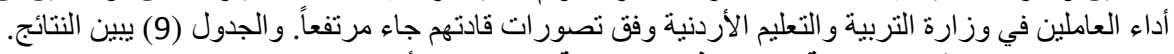

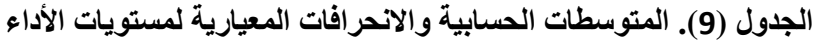

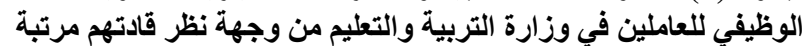
تنازلياً

\begin{tabular}{|c|c|c|c|c|c|}
\hline 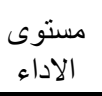 & 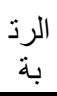 & الانحر افياري & الحستيط & 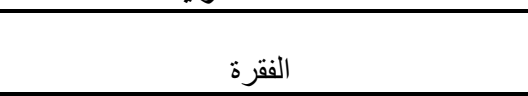 & 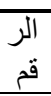 \\
\hline مرتفع & 1 & 0.91 & 4.33 & ليحافظ على أسرار العمل و لا يستخل وظبفته & 2 \\
\hline مرتفع & 2 & 0.85 & 4.32 & يستجيب لتعليمات وتوجيهات رؤسائه في العمل. & 1 \\
\hline مرتفع & 3 & 0.89 & 4.27 & يلتزم بالأنظمة و التعليمات المتعلقة بعمله. & 5 \\
\hline مرتفع & 4 & 0.88 & 4.26 & العمل. يحرص على إقامة علاقات جيدة مع رؤسائه في & 9 \\
\hline 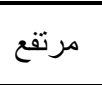 & 5 & 0.84 & 4.24 & العملة درجة عالية من المسؤولية و الإخلاص في & 6 \\
\hline مرتفع & 6 & 0.80 & 4.23 & العرل. يحرص على إقامة علاقات جيده مع زملائه في & 7 \\
\hline 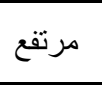 & 7 & 0.83 & 4.21 & زلديأه مهار في العمل. عالية في طرق الاتصال مع & 3 \\
\hline مرتفع & 7 & 0.90 & 4.21 & يمتلك القدرة و الكفاءة على تحمل المسؤولية. & 10 \\
\hline مرتفع & 7 & 0.92 & 4.21 & الفريق. الاستعداد للتعاون مع زملائه و العمل بروح & 18 \\
\hline مرتفع & 10 & 0.88 & 4.20 & لالعمل درجتهة عالية من الالتز ام و المو اظبة بمو اعيد & 11 \\
\hline مرتفع & 11 & 0.87 & 4.19 & جودة ودقة العمل المطلوب منه بمهنيه عالية تضمن & 16 \\
\hline مرتفع & 12 & 0.86 & 4.17 & ينظم وقته ويستخدمه في إنجاز العمل. & 14 \\
\hline مرتفع & 13 & 0.94 & 4.16 & لايه القدرة و القابلية للتطور و النمو في عمله. & 13 \\
\hline مرتفع & 14 & 0.93 & 4.14 & عيذل كافة الجهود الممكنة لرفع مستوى إنتاجية & 17 \\
\hline مرتفع & 15 & 0.91 & 4.11 & الغشارك ويبادر لحل ما يو اجهه من مشاكل أثناء & 15 \\
\hline مرتفع & 16 & 0.93 & 4.09 & من أفكار تخدرجة عالية من المرونة فيما يطرح عليه & 12 \\
\hline
\end{tabular}


Journal of Social Sciences (COES\&RJ-JSS), 7(4), pp.277-302

\begin{tabular}{|c|c|c|c|c|c|}
\hline \multirow[b]{2}{*}{ 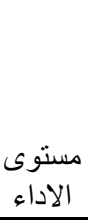 } & \multirow[b]{2}{*}{ 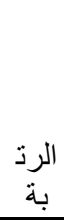 } & \multicolumn{4}{|c|}{ 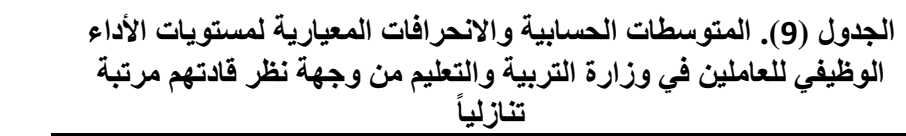 } \\
\hline & & 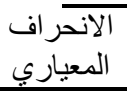 & الحستي الحسب & الفقزة & 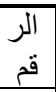 \\
\hline مرتفع & 17 & 0.98 & 4.07 & و يمتلاتكال المهارات المطتلونية في استخدام الحاسوب & 4 \\
\hline مرتفع & 18 & 1.02 & 3.98 & ويتابع تنفيذها. & 8 \\
\hline مرتفع & - & 0.74 & 4.19 & مستوى أداء العاملين (الكلي) & \\
\hline
\end{tabular}

بلغ مستوى اداء العاملين في وزارة التربية والتعليم الأردنية بثكل عام (4.19) و انحر اف معياري(0.74) وهو

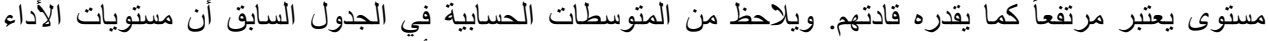

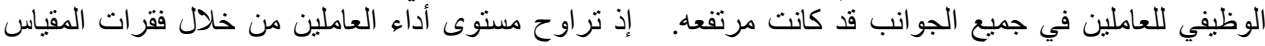

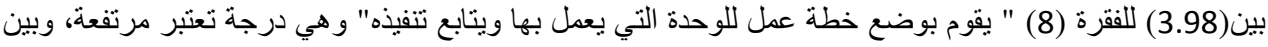

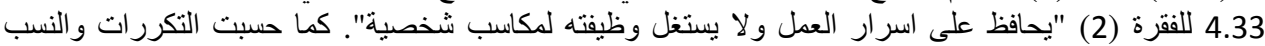

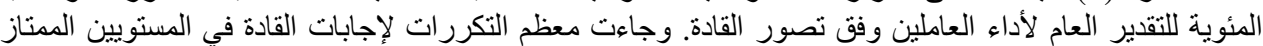

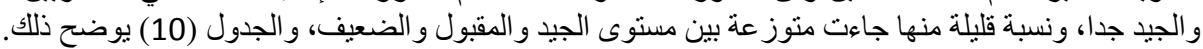

\begin{tabular}{|c|c|c|}
\hline النسبة & العدد & التققير \\
\hline 1.2 & 5 & خعيف \\
\hline 3.9 & 15 & متوسط \\
\hline 7.6 & 28 & جيد \\
\hline 39.5 & 148 & جيد جدا \\
\hline 47.7 & 178 & مهتاز \\
\hline 100.0 & 374 & لمجموع \\
\hline 13.8 & 60 & لا يوجد اجابة \\
\hline 100.0 & 434 & المجموع الكلي \\
\hline
\end{tabular}

كما أظهرت نتائج تقييم المديرين العام لأداء العاملين أن أكثر من (47.7\%) من العاملين لديهم مستوى أداء عام ممتاز ، أداء

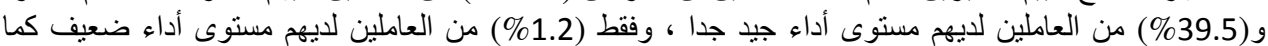

$$
\text { ير اها مديرو هم . }
$$

السؤال الثالث : ما درجة الثقة بين القادة الإداريين في وزارة التربية والتعليم الأردنية والعاملين معهم من وجهة

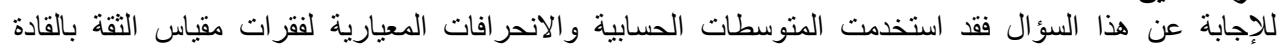

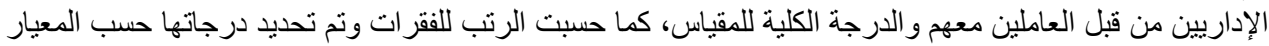
السابق، و الجدول (11) يبين النتائج:

الجدول (11). المتوسطات الحسابية والانحر افات المعيارية لارجة الثقة بين القادة

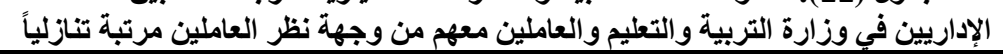


The Practicing Degree of Organizational Justice .......

\begin{tabular}{|c|c|c|c|c|c|}
\hline المستوى & 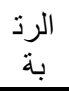 & الانحر اف المعياري & 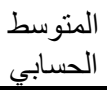 & 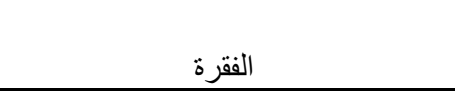 & الرقم \\
\hline مرتفع & 1 & 0.95 & 4.12 & بتقاقشير المدير العاملين عند شعوره & 24 \\
\hline مرتفع & 2 & 1.05 & 4.07 & تصنبر المدير قدوة حسنة للعاملين في & 3 \\
\hline مرتفع & 3 & 1.03 & 4.06 & يشجع المدير العاملين على القيام بالعمل. & 5 \\
\hline مرتفع & 4 & 0.98 & 4.05 & يثق المدير بأداء العاملين في العمل. & 14 \\
\hline 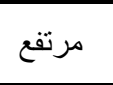 & 5 & 0.97 & 4.04 & العاملين المدير عاجى التوفيق بين حاجات & 18 \\
\hline 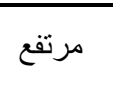 & 6 & 0.95 & 4.03 & لأداء المهام الإدارية. المدير المعلومات الصادقة اللازمة & 13 \\
\hline 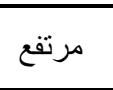 & 7 & 0.97 & 4.02 & لتحقيق الأهداف المدير رؤيا و إستر اتيجية و اضحة. & 12 \\
\hline 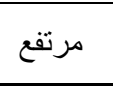 & 7 & 0.98 & 4.02 & من رضر العامين. & 1 \\
\hline 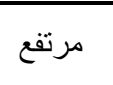 & 7 & 1.06 & 4.02 & للمدير ثقة عالية بنفسه تنعكس على & 17 \\
\hline 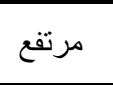 & 10 & 1.02 & 3.99 & للعمل. لمتلك المدير رؤية مستقبلية واضحة & 21 \\
\hline مرتفع & 11 & 1.04 & 3.94 & بتعامل المدير بعدالة مع العاملين. & 4 \\
\hline مرتفع & 11 & 1.05 & 3.94 & يتفهم المدير بعقلانية ظروف العاملين. & 22 \\
\hline 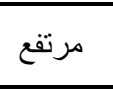 & 11 & 1.00 & 3.94 & مشاكلهم. ميتعاون المدير مع العاملين في حل & 19 \\
\hline 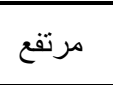 & 14 & 0.98 & 3.92 & صيشجع المدير العاملين على المشاركة في & 2 \\
\hline 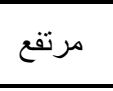 & 15 & 1.07 & 3.91 & و الإبداع المدير العاملين على الابتكار & 16 \\
\hline 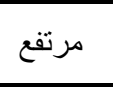 & 15 & 0.99 & 3.91 & جطيق المو اقدير الأنظمة و التعليمات في & 11 \\
\hline مرتفع & 15 & 1.04 & 3.91 & إدارته فئ لدى المدير سياسات و اضحة في & 7 \\
\hline مرتفع & 18 & 1.03 & 3.90 & يفوض المدير السلطات للعاملين. & 15 \\
\hline 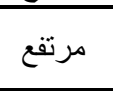 & 19 & 1.01 & 3.88 & 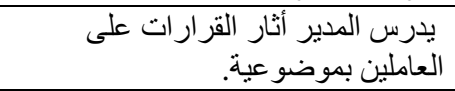 & 23 \\
\hline مرتفع & 20 & 1.03 & 3.86 & القرارات. & 8 \\
\hline 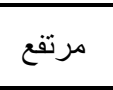 & 20 & 1.00 & 3.86 & الموضذ المدير قرار اته بدرجة عالية من & 6 \\
\hline 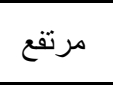 & 22 & 0.97 & 3.83 & للعاملين. & 9 \\
\hline مرتفع & 23 & 1.04 & 3.82 & يتقبل المدير النقد البناء من العاملين. & 20 \\
\hline مرتفع & 23 & 1.17 & 3.82 & لا يستمع المدير إلى من يوشي بزميله. & 10 \\
\hline مرتفع & - & 0.84 & 3.95 & الدرجة الكلية & \\
\hline
\end{tabular}

بلغت درجة ثقة العاملين في وزارة التربية والتعليم الأردنية بمديريهم بشكل عام 3.95 و انحر اف معياري (0.84)

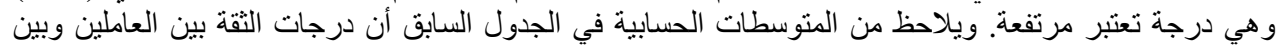




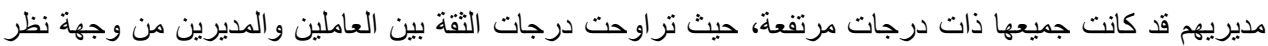

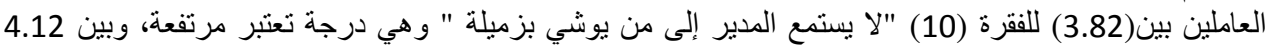

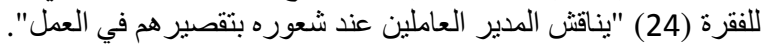

السؤال الرابع: هل توجد علاقة بين درجة ممارسة القادة الإداريين في وزارة التربية والتعليم الأردنية للعدالة

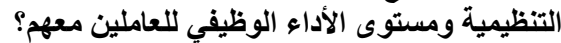

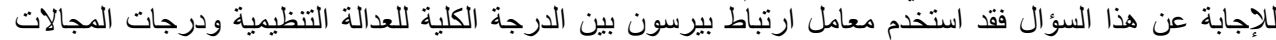

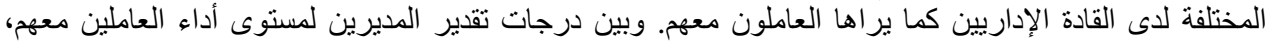
و الجدول (12) يبين ذلك.

الجدول (12). معامل ارتباط بيرسون للعلاقة بين درجة ممارسة القادة الإداريين للعدالة التنظيمية ومستوى أداء

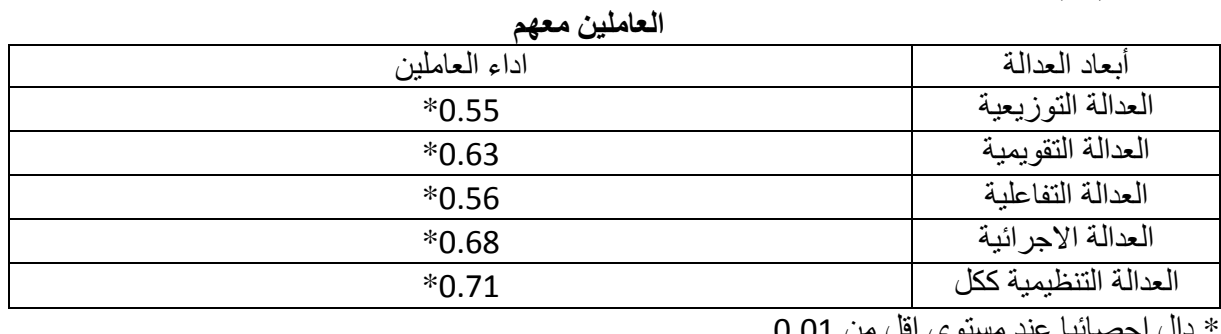

بلغ معامل ارتباط بيرسون بين الدرجة الدائن الكلية للعدالة التنظيمية لدى القادة الإداريين كما ير اها العاملون معهم، وبين

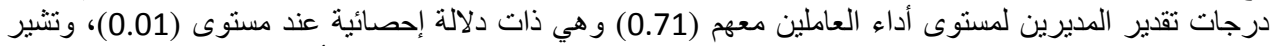

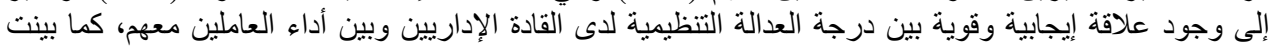

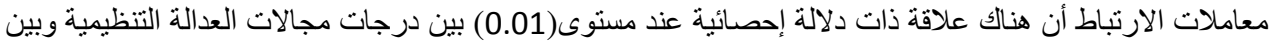

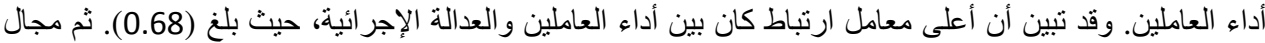

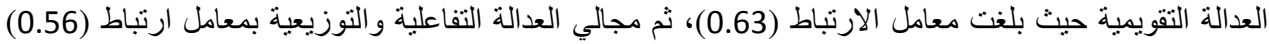
السؤال الخامس: هل لونة توجد علاقة بين درجة ممارسة القادة الإداريين في وزارة التربية والتعليم الأردنية للعدالة و (0.55) على الترتيب.

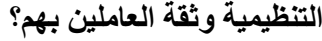

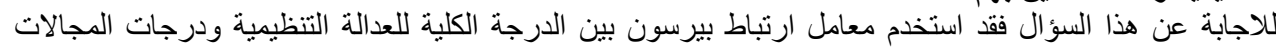

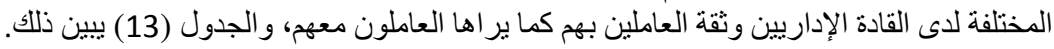

الجدول (13). معامل ارتباط بيرسون بين درجة ممارسة القادة الإداريين للعدالة التظظيمية وثقة العاملين بهم

\begin{tabular}{|c|c|}
\hline ثقة العاملين بقادتهم & أبعاد العدالة التنظيمية \\
\hline$* 0.77$ & العدالة التوزيعية \\
\hline$* 0.83$ & العدالة التقويمية \\
\hline$* 0.87$ & العدالة التفاعلية \\
\hline$* 0.87$ & العدالة الاجر ائية \\
\hline$* 0.87$ & العدالة التنظيمية الكلية \\
\hline
\end{tabular}

0.01 من 0.0

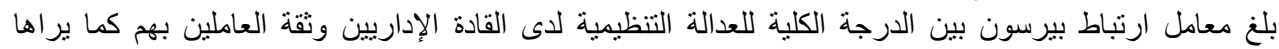

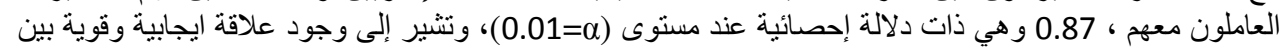

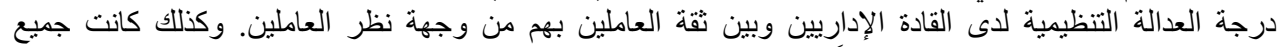

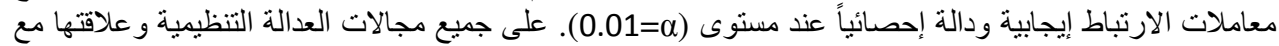
ثقة العاملين برؤسائهم.

مناقشة النتائج و التوصيات

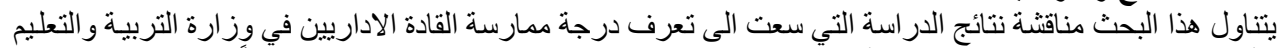

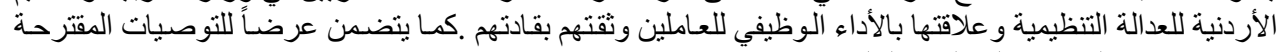
في ضوء نتائج الار اسة على النحو التالي: 


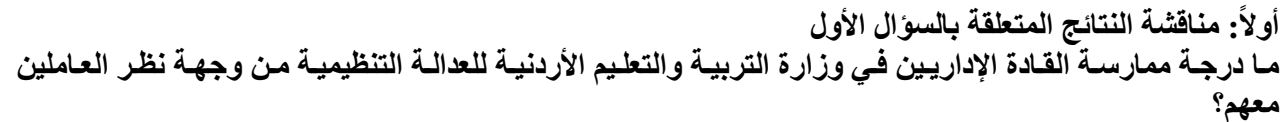
أظهرت نتائج هذه الدر اسة أن درجة ممارسة القادة الإداريين في وزارة التربية و التعليم الأردنية للعدالة التنظيمية بشكل

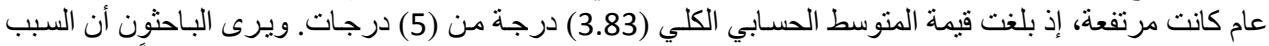

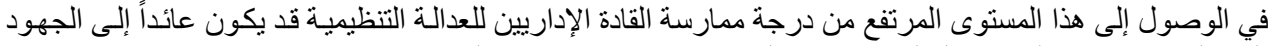

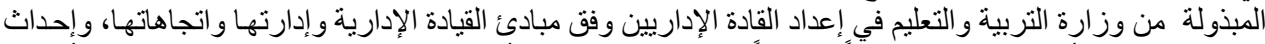

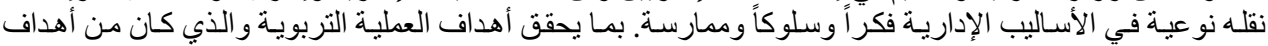

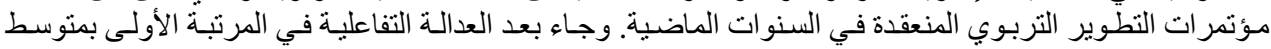

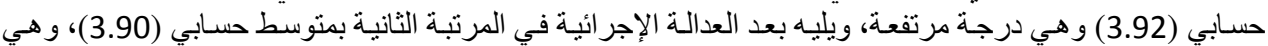

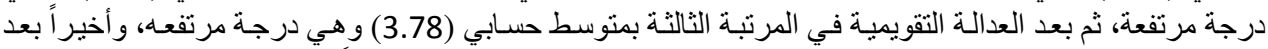

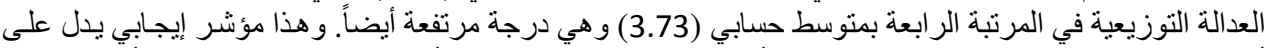

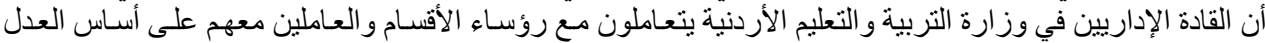

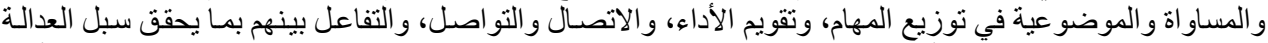

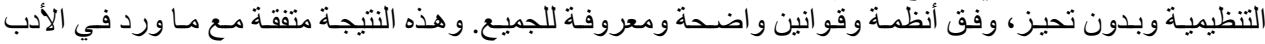

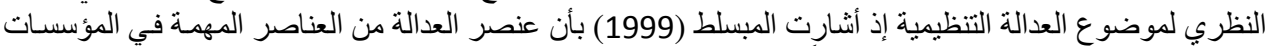

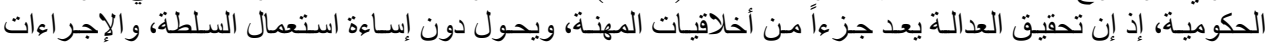

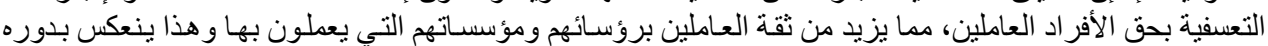

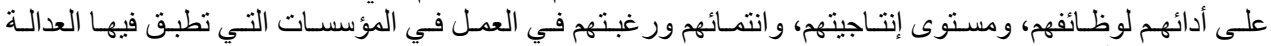

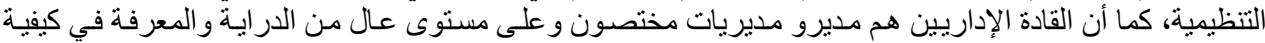

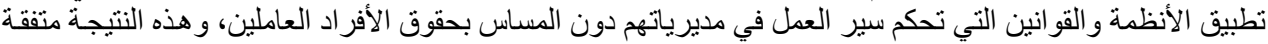
مع نتائج دراسة كل من (الحو امده،

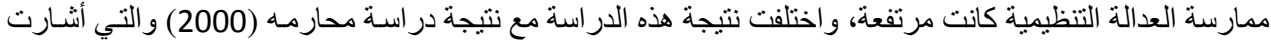

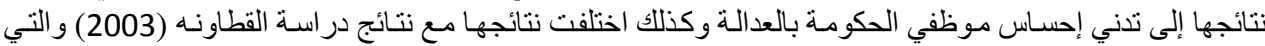

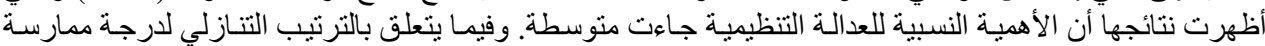

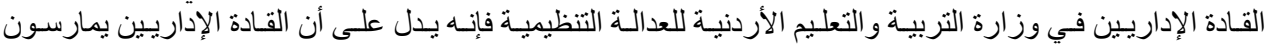

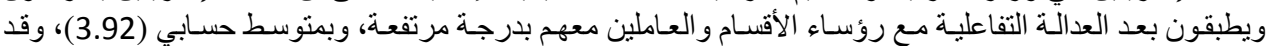

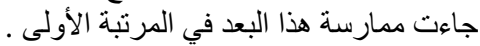
بُعد العدالة التفاعلية

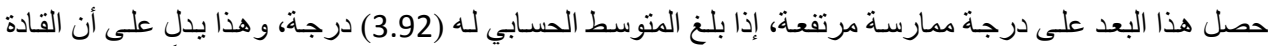

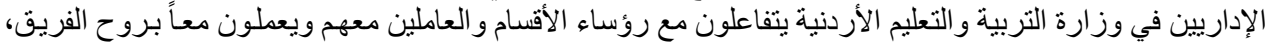

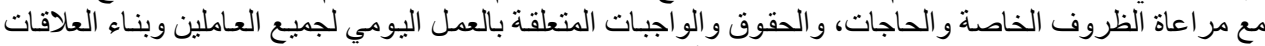

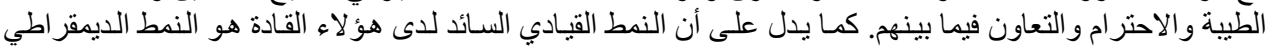

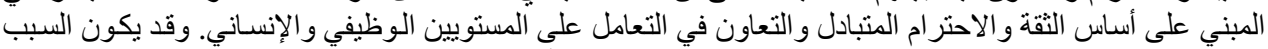

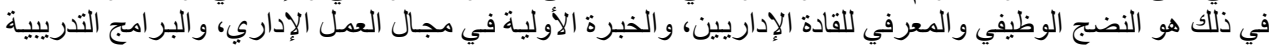

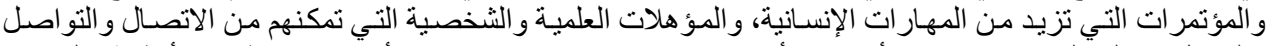

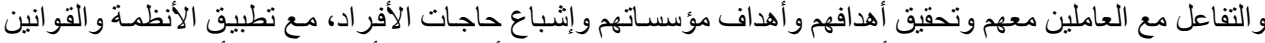

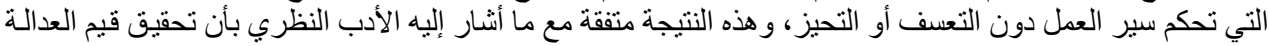

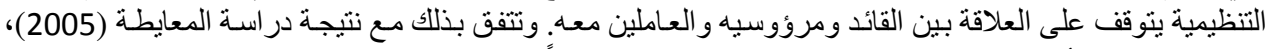

سلطان (2006) بأن درجة ممارسة بعد العدالة التفاعلية كان مرتفعاً. بُعد العدالة الإجرائية

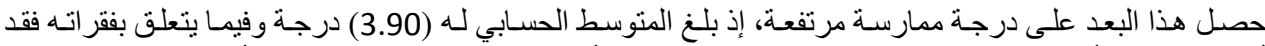

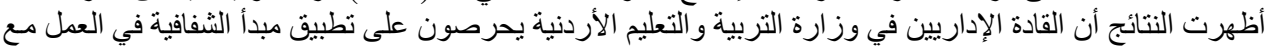

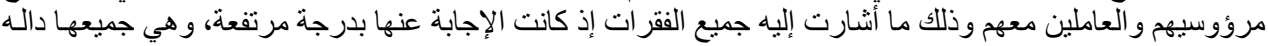

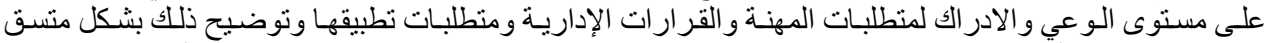

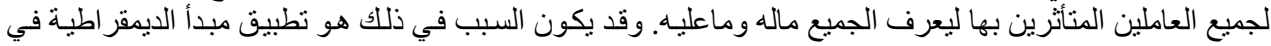

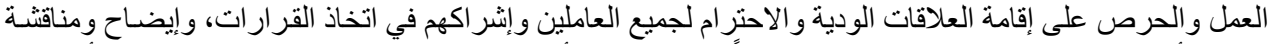

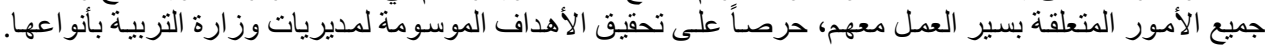


و هذه النتيجة تتفق مع نتيجة در اسة الحو امده (2002) و المعايطة (2005)، وسلطان (2006) بأن درجة ممارسـة بعد العدالة الإجر ائية كان مرتفعاً.

بُعد العدالة التقويمية

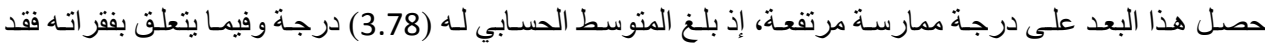

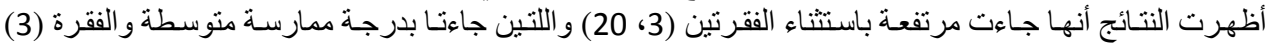

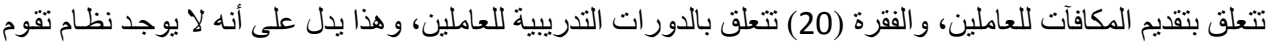

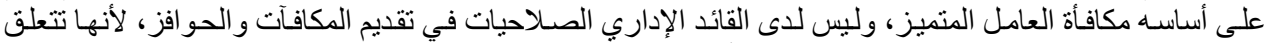

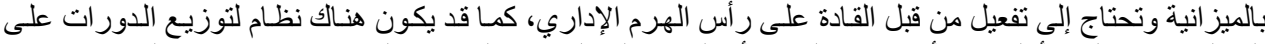

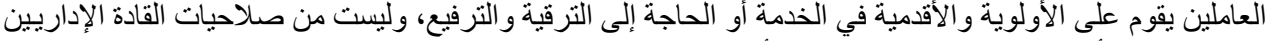

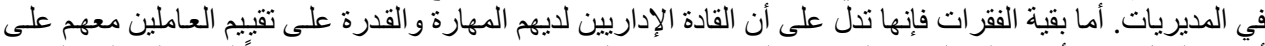

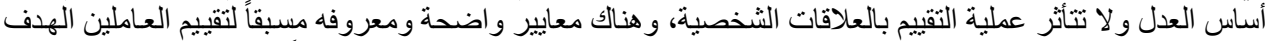

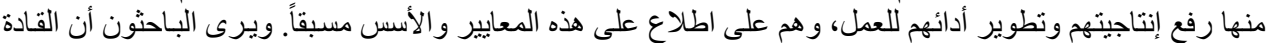

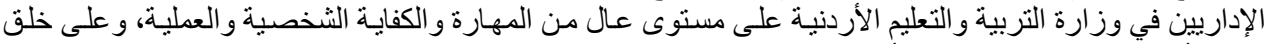

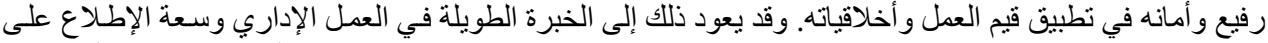

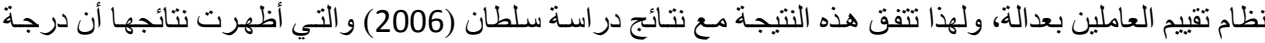
ممارسة بعد العدالة التقييمية مرتفعة. بُعد العدالة التوزيعية

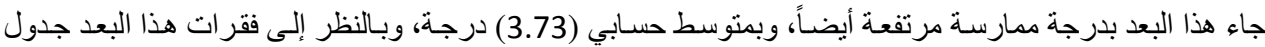

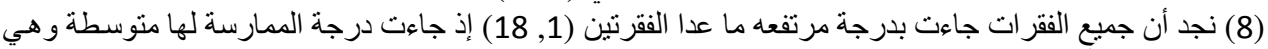

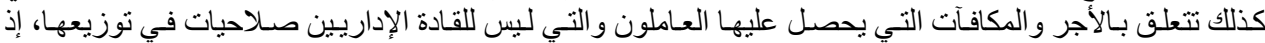

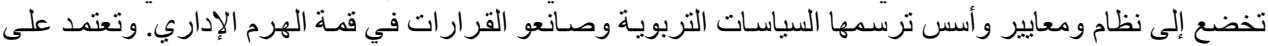

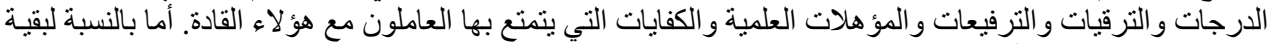

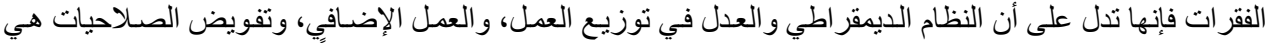

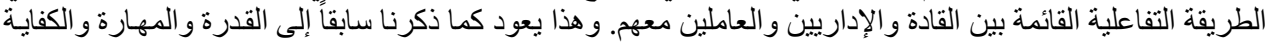

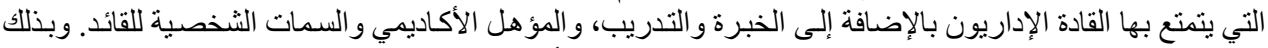

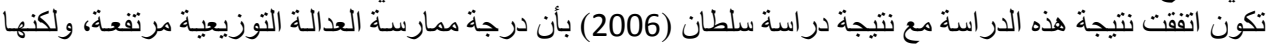

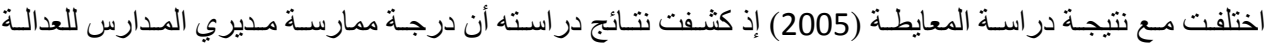
التوزيعية كانت متوسطة

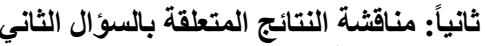

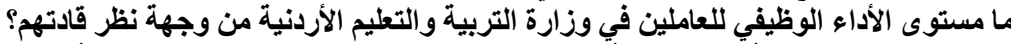

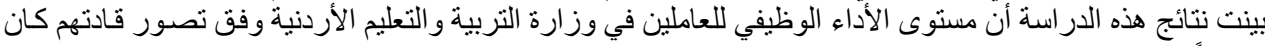

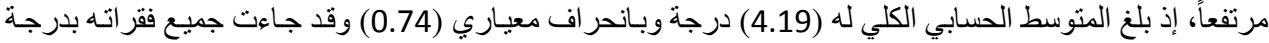

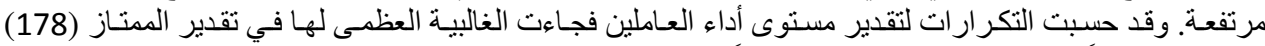

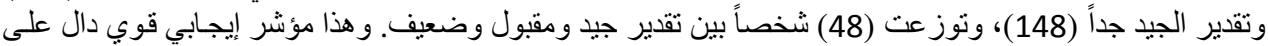

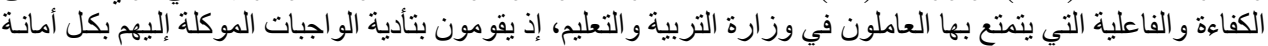

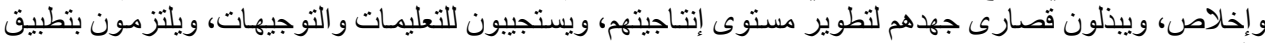

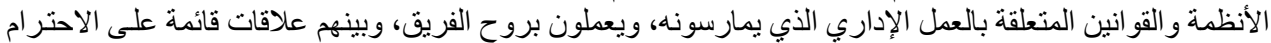

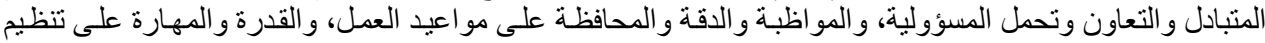

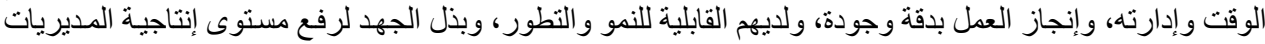

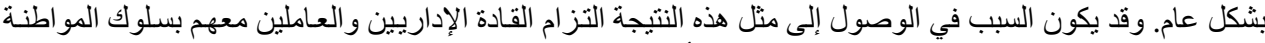

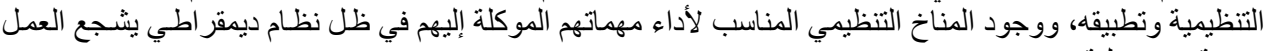

بحرية ومسؤولية.

كما قد يكون للتدريب و الدور اتلة التدريبية، وحصول الموظفين على الترقيات و الترفيعات وزيـادة دخولهم الماديـة الدور

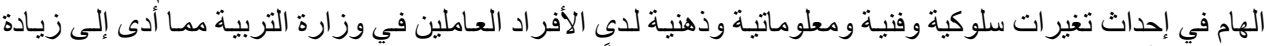

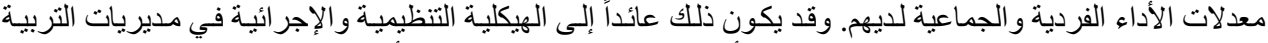

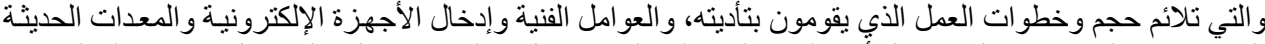

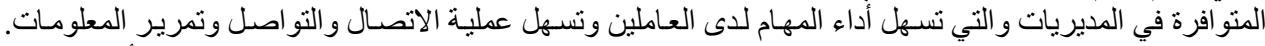

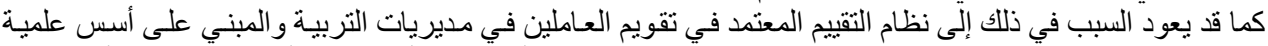

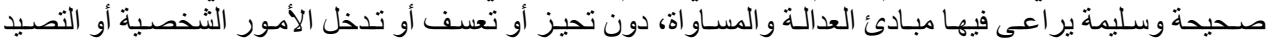

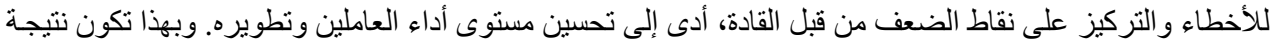


هذه الدراسة قد اتفقت مع نتيجة در اسة الصر ايره (2005) بأن مستوى الأداء لأعضاء الهيئات التدريسية في الجامعات

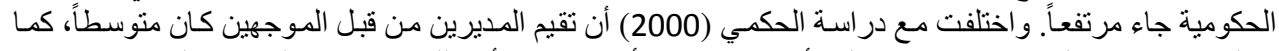

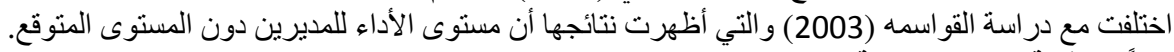

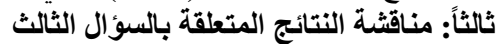

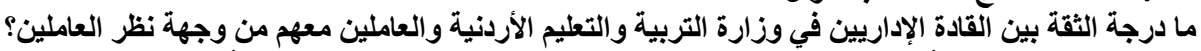

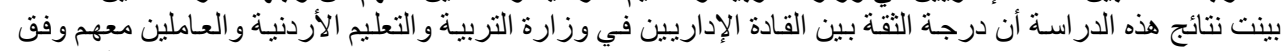

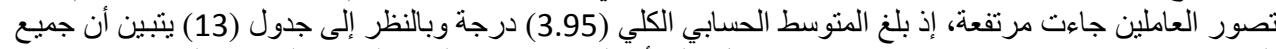

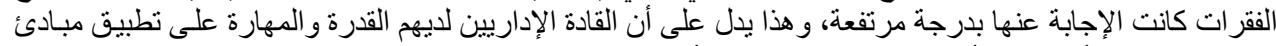

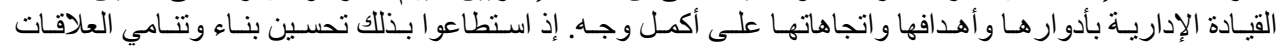

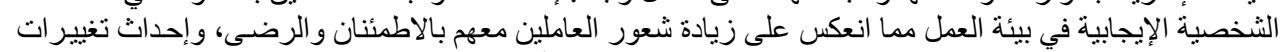

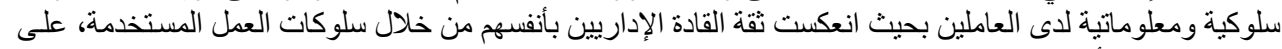

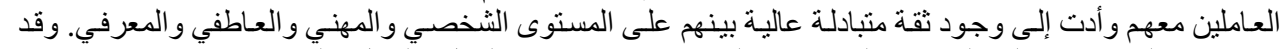

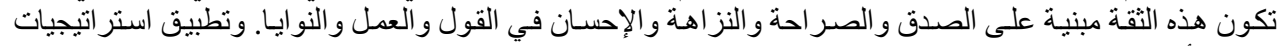

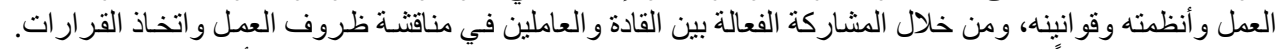

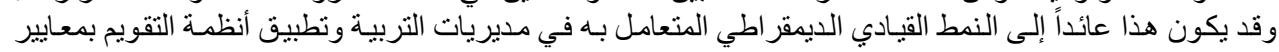

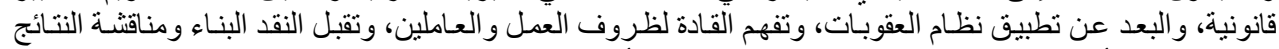

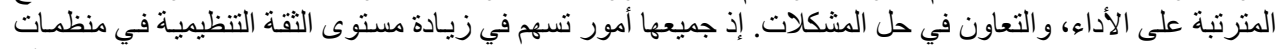

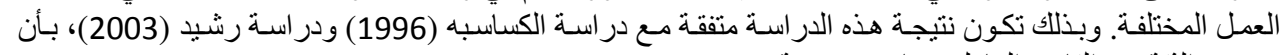

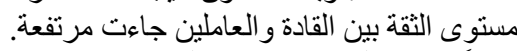

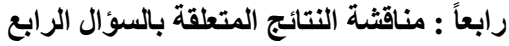

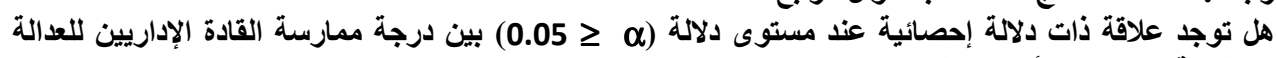
التنظيمية ومستوى الأداء الوظيفي للعاملين؟

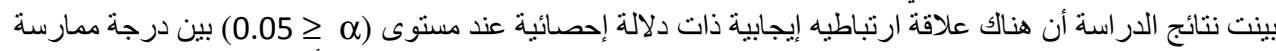

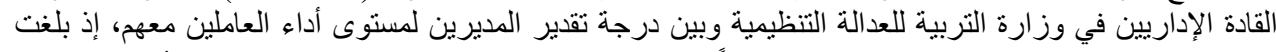

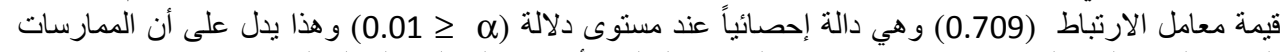

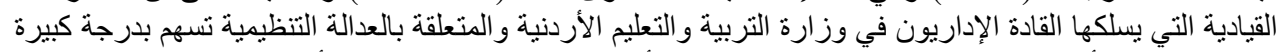

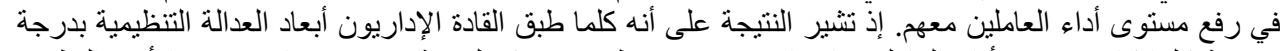

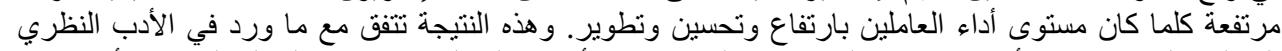

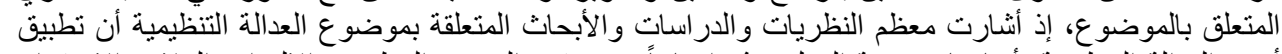

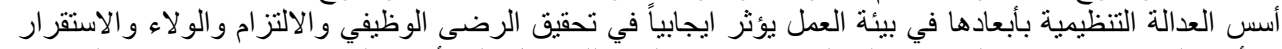

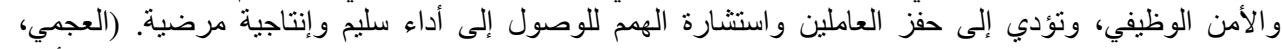

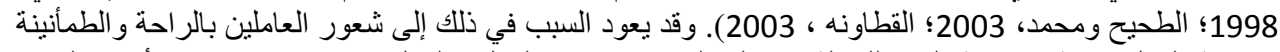

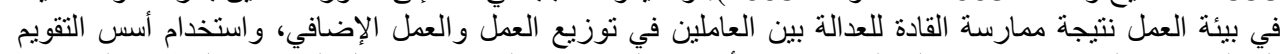

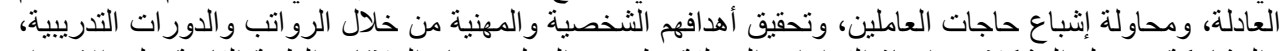

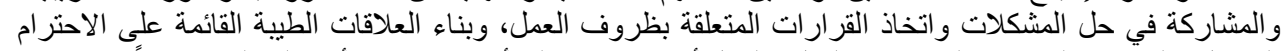

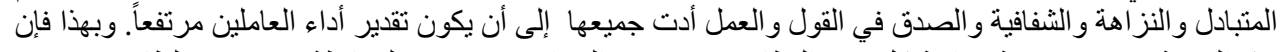

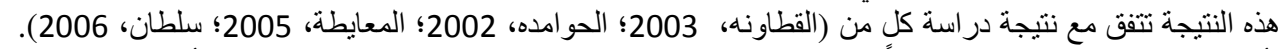

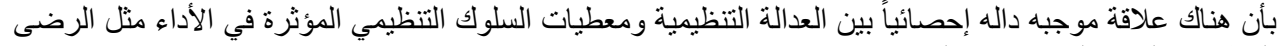

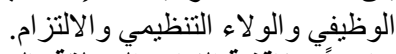

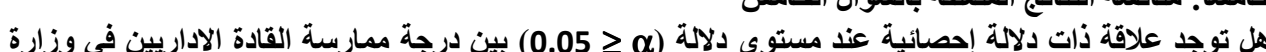

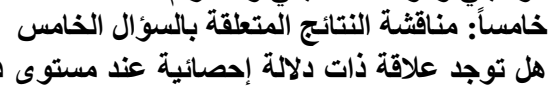

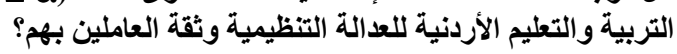

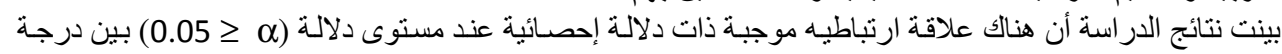

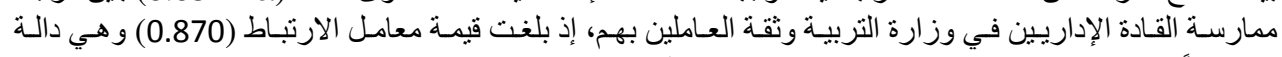

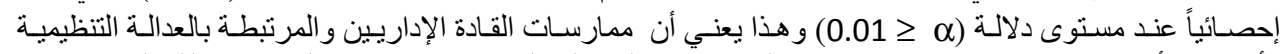

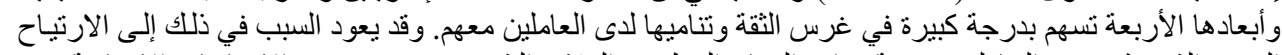

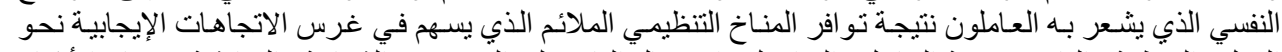

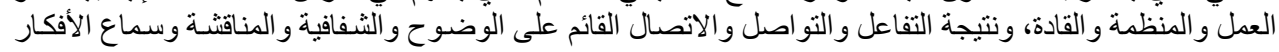




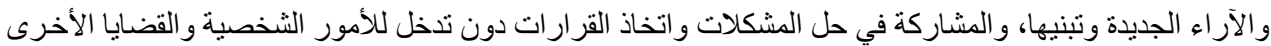

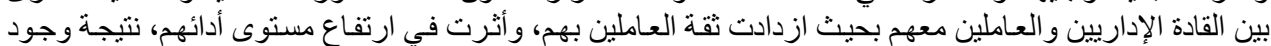

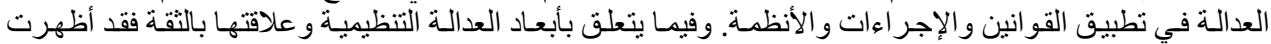

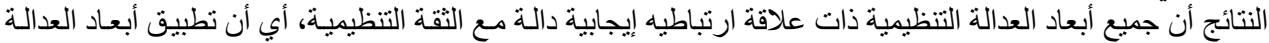

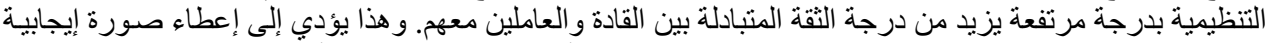

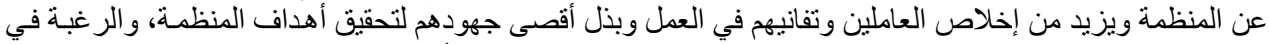

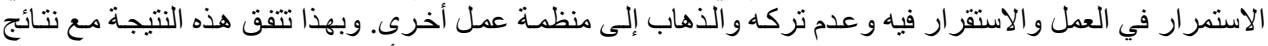

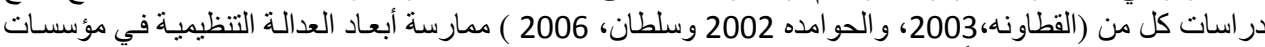

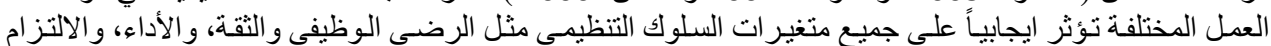

بناءً على ما توصلت إليه الدر اسة من نتائج، فإنها توصي بالآتي:

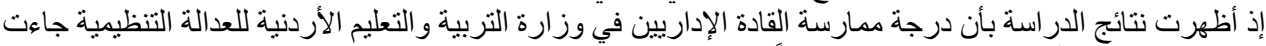

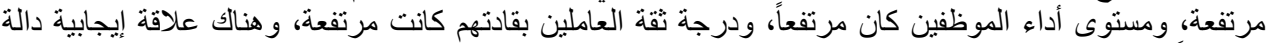

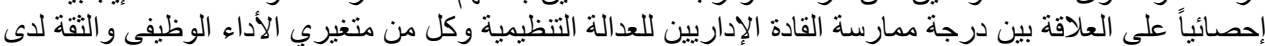

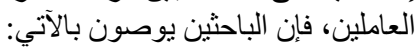

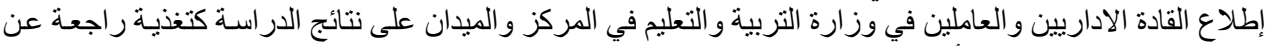

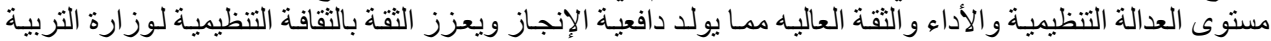
و التعليم الأردنية.

عمل ندو ات لبيان أهمية العدالة التظيمية و أثر ها على مستوى الأداء و وعلى المناخ التنظيمي بشكل عام.

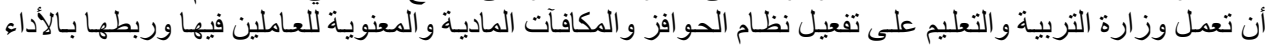

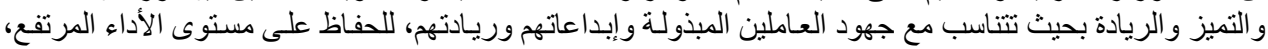
وتعزيز مستوى الثقة المرتفعة بين القادة و العاملين.

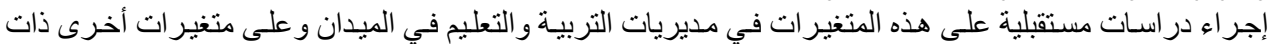

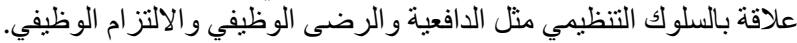

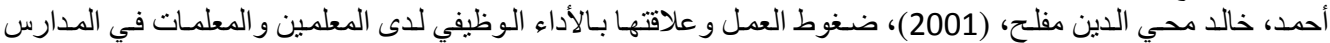

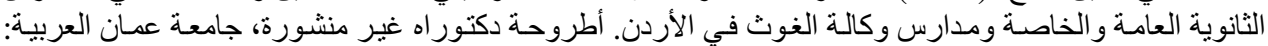
عمان، الأردن.

الجر ادين، نجـاح خليل، (2004)، الاداء الوظيفي لمديريـي المدارس الثانويـة العامـة في الاردن و علاقتـة بمستوى، جامعـة

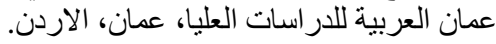

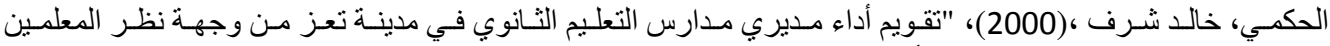

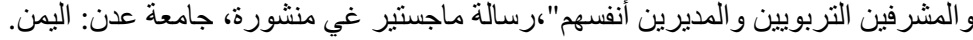

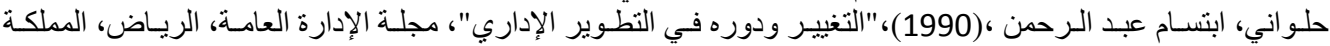

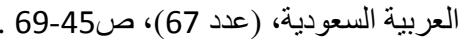

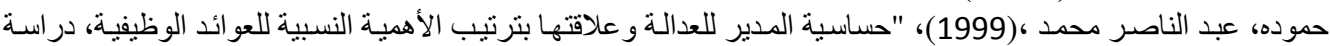

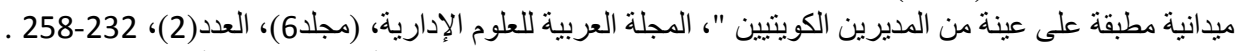

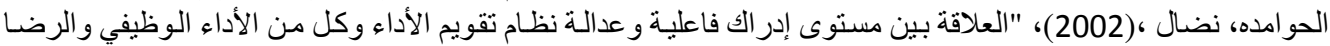

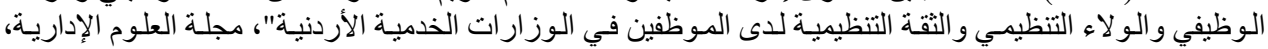

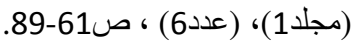

الذنيبات، حسـام مبـارك ،(2003)، ، (203)، العلاقـة بـين نظم المعلومـات الإداريـة المحوسبة و أداء العـاملين في المؤسسـات الماليـة

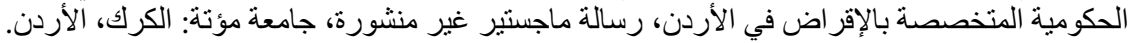
راويه، حسن محمد ،(2001)، "إدارة الموارد البشرية: رؤية مستقبلية"،القاهرة ،الدار الجامعية.

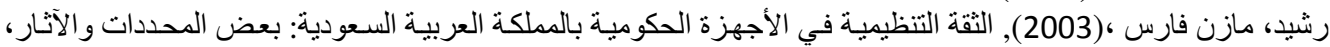

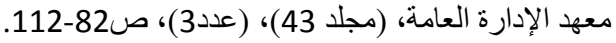

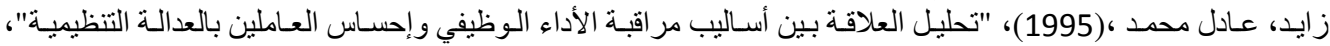

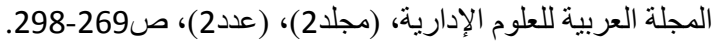




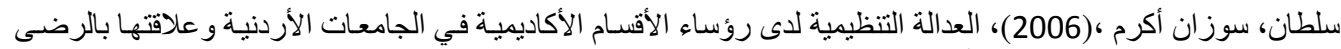

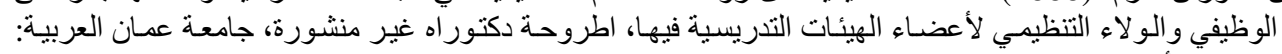

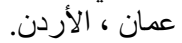

سيز لاقي، أندرودي، الاردي، والاس مـارك جي ،(1991)، "السلوك التنظيمي والأداء"، ترجمة جعفر أبو القاسم أحمد، الرياض،

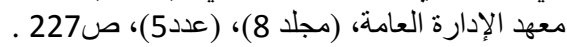

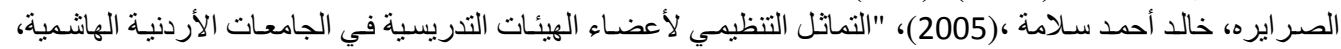

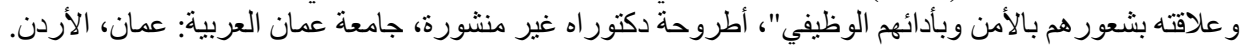

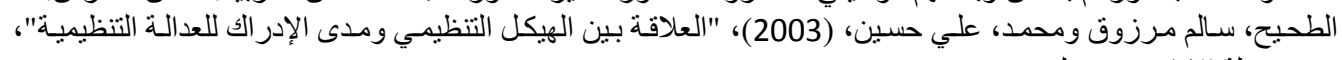

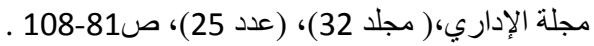

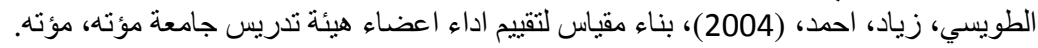

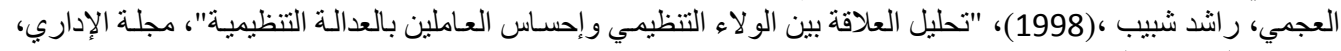

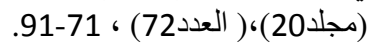

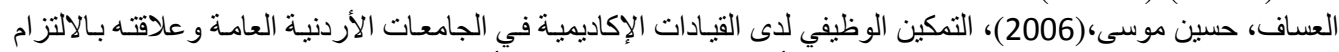

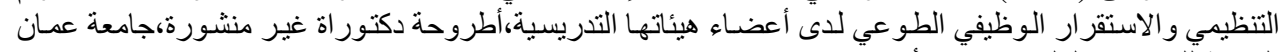

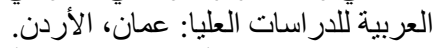

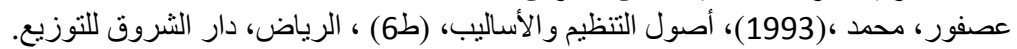

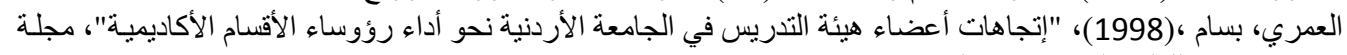

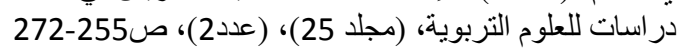

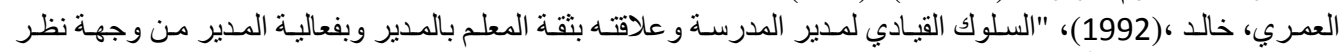

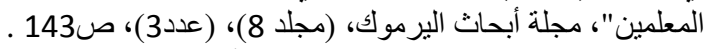

الغامدي، عبداله، (1999)، "الثقلة التنظيميـة بـالأجهزة الإداريـة في المملكة العربيـة السـودية "، المجلـة العربيـة للإدارة،

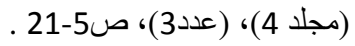

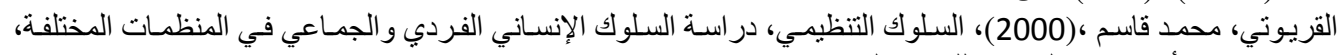
عمان، الأردن ,دار الثروق اللنشر و التوزيع.

القطاونه، نثأت أحمد ،(2003)، تأثير العدالة التنظيمية في الو لاء التنظيمي. رسالة ماجستير غير منشوره، جامعة مؤتنة:

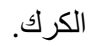

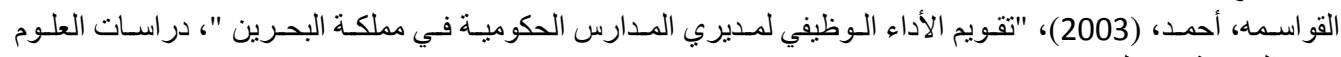

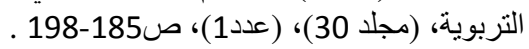

الكساسبه، محمد مفضي ،(1996)، العو امل المؤثرة في الثقة التتظيمية، دراسة ميدانية على أجهزة الخدمة المدنية الأردنية.

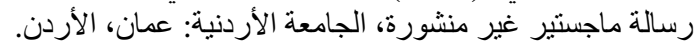

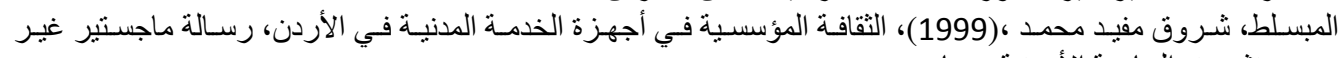
منشورة، الجامعة الأردنية: عمان.

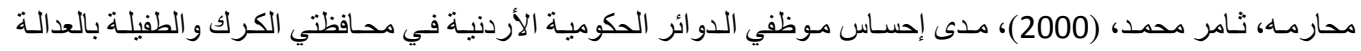

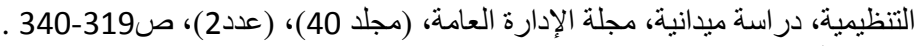

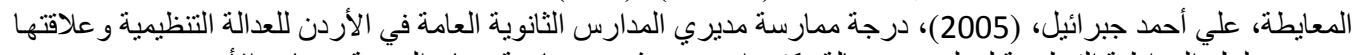

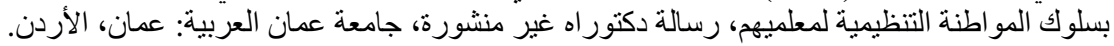

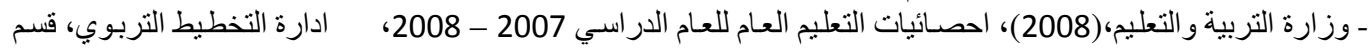

\section{References}

الاحصاء.

المراجع الإنجليزيـة

Abualoush, S., Masa'deh, R., Bataineh, K., \& Alrowwad, A. (2018). The Role of Knowledge Management Process and Intellectual Capital as Intermediary Variables between Knowledge Management Infrastructure and Organization Performance. Interdisciplinary Journal of Information, Knowledge, and Management, 13, 279-309. 
Journal of Social Sciences (COES\&RJ-JSS), 7(4), pp.277-302

Alenezi, H., Tarhini, A., Alalwan, A., \& Al-Qirim, N. (2017). Factors Affecting the Adoption of EGovernment in Kuwait: A Qualitative Study. Electronic Journal of e-Government, 15(2), 84-102.

Alkandari, A., Masa'deh, R., \& Al-Lozi, M. (2017). Knowledge Management and its Role on Organizational Crisis Management: A Literature Review. Journal of Social Sciences (COES\&RJ-JSS), 6(4), 833-850.

AL-Lozi, M. (2002). Total Quality Management in the Civil Service institutions in Jordan. Mu'tah: Humanities and Social Sciences Series, 18(4), 151-185.

AlHarrasi, J., \& AL-Lozi, M. (2015). The Role of Innovation Management and Technological Innovation on Organizational Effectiveness. 4th Scientific \& Research Conference on New Trends in Business, Management and Social Sciences (COES\&RJ-TK15/1), Istanbul, Turkey.

AlHarrasi, J., \& AL-Lozi, M. (2016). The Role of Innovation Management and Technological Innovation on Organizational Effectiveness: A Theoretical Model. Journal of Social Sciences (COES\&RJ-JSS), 5(1), 80-95.

AlHrassi, J., Al-Lozi, M., \& Irtaimeh, H. (2016). The Impact of Management Innovation and Technological Innovation on Organizational Effectiveness: An Empirical Study from Managerial Staff Perspective in Sultan Qaboos University. Journal of Social Sciences (COES\&RJ-JSS), 5(3), 309-339.

Almajali, D., Masa'deh, R., \& Al-Lozi, M. (2016). Determinants of the Actual Use of E-Learning Systems: An Empirical Study on Zarqa University in Jordan. Journal of Social Sciences (COES\&RJ-JSS), 5(2), 172-200.

AL-Syaidh, N., Al- Lozi, M., \& AlHarrasi, J. (2016). Transformational Leadership and its Role on the Effectiveness of Employees' Behavior: A Theoretical Study. Journal of Business \& Management (COES\&RJ-JBM), 4(1), 14-35.

AL-Syaidh, N., Masa'deh, R., \& Al-Zu'bi, Z. (2014). Transformational Leadership and its Impact on the Effectiveness of Employees' Behavior in the Public and Private Jordanian Hospitals. Jordan Journal of Business Administration, 11(1), 23-57.

Ammari, G., Alkurdi, B., Alshurideh, A., \& Alrowwad, A. (2017). Investigating the Impact of Communication Satisfaction on Organizational Commitment: A Practical Approach to Increase Employees' Loyalty. International Journal of Marketing Studies, 9(2), 113-133.

Arnold, E., \& Pulich, M. (2003). Managing Effectively in the Downsized Organization. Health Care Manager, 22(1), 56-62.

Ball, G.A., Trevino, L.K., \& Sims, H.P. (1994). Justice and Justice Punishment: Influence on Subordinate Performance and Citizenship. Academy of Management Journal, 37(2), 209222. 
Byars, L., \& Rue, L. (1997). Human Resource Management, $5^{\text {th }}$ Edition, New York, Irwin MCGRAW Hill, Companies, Inc.

Caudron, S. (2004). Pebuilding Employee Trust, Workforce, Management, Vendor Directory.

Darawsheh, S., ALshaar, A., \& AL-Lozi, M. (2016). The Degree of Heads of Departments at the University of Dammam to Practice Transformational Leadership style from the Point of View of the Faculty Members. Journal of Social Sciences (COES\&RJ-JSS), 5(1), 56-79.

Duffy, B. (2003). Who do We Trust, MORL, Research Methods Unit, $7^{\text {th }}$ Edition, New York: John Wiley sons, USA.

Fimian, E. (1994). Managing Performance, California: Basic Books.

Gibson, T.A. (1994). Organization Behavior Structure and Processes, Boston, Mass Irwin, 173.

Gillies, D.A. (1994). Nursing Management: A System Approach, Philadelphia: Sanders Company.

Greenberg, D. (1990). Organizational Justice: Yesterday, Today, and Tomorrow. Journal of Management, 16, 606-613.

Greenberg, J., \& Cropanzano, R. (2001). Advances in Organizational Justice, Stand ford University Press in California.

Khalayleh, W., Masa'deh, R., \& Al-Lozi, M. (2017). Administrative Empowerment and its Role on the Work Teams Performance: A Literature Review. Journal of Social Sciences (COES\&RJ-JSS), 6(4), 851-868.

Khwaldeh, S., Al-Hadid, I., Masa'deh, R., \& Alrowwad, A. (2017). The Association between EServices Web Portals Information Quality and ICT Competence in the Jordanian Universities. Asian Social Science, 13(3), 156-169.

Masa'deh, R., Alrowwad, A., Alkhalafat, F., Obeidat, B., \& Abualoush, S. (2018). The Role of Corporate Social Responsibility in Enhancing Firm Performance from the Perspective of IT Employees in Jordanian Banking Sector: The Mediating Effect of Transformational Leadership. Modern Applied Science, 12(7), 1-26.

Masa'deh, R., Obeidat, B., Zyod, D., \& Gharaibeh, A. (2015). The Associations among Transformational Leadership, Transactional Leadership, Knowledge Sharing, Job Performance, and Firm Performance: A Theoretical Model. Journal of Social Sciences (COES\&RJ-JSS), 4(2), 848-866.

Mikkawi, B., \& Al-Lozi, M. (2017). The Impact of Knowledge Management Infrastructure on Academic Staff Effectiveness: An Empirical Study at The University of Jordan. Jordan Journal of Business Administration, 13(1), 95-127. 
Journal of Social Sciences (COES\&RJ-JSS), 7(4), pp.277-302

Obeidat, O., Tarhini, A., \& Aqqad, N. (2017). The Impact of Intellectual Capital on Innovation via the Mediating Role of Knowledge Management: A Structural Equation Modeling Approach. International Journal of Knowledge Management Studies, 8(3/4), 273-298.

Ogilvy, J. (1995). The Economics of Trust. Harvard Business Review, 46-47.

Shannak, R., \& Obeidat, B. (2012). Culture and the Implementation Process of Strategic Decisions in Jordan. Journal of Management Research, 4(4), 257-281.

Tarhini, A., Mgbemena, C., \& Trab, MSA. (2015). User Adoption of Online Banking in Nigeria: A Qualitative Study. Journal of Internet Banking and Commerce, 20(3), 1-8.

Wayne. S., Shore, L.M., \& Liden, R.C. (1997). Perceived Organizational Support and Leader Member Exchange: A Social Exchange Perspective. Academy of Management Journal, $40(1)$.

Whitener, E. (1997). The Impact of Humman Resource Activities on Employee Trust. Human Resource Management Review, 7(4), 389-404.

Yassien, E., \& Mufleh, M. (2017). The Impact of ERP System's Usability on Enterprise Resource Planning Project Implementation Success via the Mediating Role of User Satisfaction. Journal of Management Research, 9(3), 49-71. 